\title{
Geochemical evidence of mantle reservoir evolution during progressive rifting along the western Afar margin
}

\author{
Tyrone O. Rooney ${ }^{\mathrm{a}, *}$, Paul Mohr ${ }^{\mathrm{b}}$, Laure Dosso ${ }^{c}$, Chris Hall ${ }^{\mathrm{d}}$
}

\author{
${ }^{a}$ Dept. of Geological Sciences, Michigan State University, East Lansing, MI 48824, USA \\ b Tonagharraun, Corrandulla, Co. Galway, Ireland \\ ${ }^{c}$ Laboratoire Domaines Océaniques, UMR 6538, CNRS, Ifremer, 29280 - Plouzané, France \\ ${ }^{d}$ Dept. of Earth and Environmental Sciences, University of Michigan, Ann Arbor, MI 48109, USA \\ *: Corresponding author : Tyrone O. Rooney, Tel.: +1 5174325522 ; email address : rooneyt@msu.edu
}

\begin{abstract}
:
The Afar triple junction, where the Red Sea, Gulf of Aden and African Rift System extension zones converge, is a pivotal domain for the study of continental-to-oceanic rift evolution. The western margin of Afar forms the southernmost sector of the western margin of the Red Sea rift where that margin enters the Ethiopian flood basalt province. Tectonism and volcanism at the triple junction had commenced by $\sim 31 \mathrm{Ma}$ with crustal fissuring, diking and voluminous eruption of the Ethiopian-Yemen flood basalt pile. The dikes which fed the Oligocene-Quaternary lava sequence covering the western Afar rift margin provide an opportunity to probe the geochemical reservoirs associated with the evolution of a still active continental margin. ${ }^{40} \mathrm{Ar} /{ }^{39} \mathrm{Ar}$ geochronology reveals that the western Afar margin dikes span the entire history of rift evolution from the initial Oligocene flood basalt event to the development of focused zones of intrusion in rift marginal basins. Major element, trace element and isotopic ( $\mathrm{Sr}-\mathrm{Nd}-\mathrm{Pb}-\mathrm{Hf})$ data demonstrate temporal geochemical heterogeneities resulting from variable contributions from the Afar plume, depleted asthenospheric mantle, and African lithosphere. The various dikes erupted between $31 \mathrm{Ma}$ and $22 \mathrm{Ma}$ all share isotopic signatures attesting to a contribution from the Afar plume, indicating this initial period in the evolution of the Afar margin was one of magma-assisted weakening of the lithosphere. From $22 \mathrm{Ma}$ to $12 \mathrm{Ma}$, however, diffuse diking during continued evolution of the rift margin facilitated ascent of magmas in which depleted mantle and lithospheric sources predominated, though contributions from the Afar plume persisted. After $10 \mathrm{Ma}$, magmatic intrusion migrated eastwards towards the Afar rift floor, with an increasing fraction of the magmas derived from depleted mantle with less of a lithospheric signature. The dikes of the western Afar margin reveal that magma generation processes during the evolution of this continental rift margin are increasingly dominated by shallow decompressional melting of the ambient asthenosphere, the composition of which may in part be controlled by preferential channeling of plume material along the developing neo-oceanic axes of extension.
\end{abstract}

\section{Introduction}

Early quantitative tectonic models explained the generation of mantle melt in extensional zones in terms of simple adiabatic decompression of the asthenosphere (e.g., White and McKenzie, 1989). However, the stresses required to rupture typical continental lithosphere may not be available from plate tectonic processes alone, and hybrid models were subsequently developed in 
45 which magma provides additional impetus for lithospheric rifting (e.g., Buck, 2004; Buck, 2006;

46 Bialas et al., 2010). Lateral variations in lithospheric thickness and rheology may also localize

47 strain and magmatism during rifting (e.g., Ebinger and Sleep, 1998; van Wijk et al., 2008).

48 Upwelling, buoyant asthenosphere contributes to plate driving forces, and may generate

49 significant volumes of melt across a broad region (e.g., Huismans et al., 2001). The presence of

50 buoyant melt can facilitate the intrusion of dikes into thick continental lithosphere at

51 comparatively small extensional stresses, and this heating can significantly reduce the strength of

52 the plate, further facilitating extension (e.g., Fialko and Rubin, 1999; Buck, 2004; Bialas et al.,

53 2010). Thus, the initial phase of rifting above a mantle plume may be marked by a pulse of

54 widespread dike intrusion (e.g., Renne et al., 1996; Fialko and Rubin, 1999; Klausen and Larsen,

55 2002). During the later stages of continental rifting, extension occurs principally by dike

56 intrusion into a thinned lithosphere (Ebinger and Casey, 2001; Keranen et al., 2004; Rooney et

57 al., 2005; Daly et al., 2008; Keir et al., 2009; Bastow et al., 2010; Ebinger et al., 2010; Wright et

58 al., 2012), before a final stage of plate stretching and associated decompression melting

59 characterizing the final stages of continent-ocean transition (e.g., Bastow and Keir, 2011). Key

60 unresolved questions remain concerning the geochemical signature(s) of the melt sources during

61 the initial stages of continental rifting, and the evolution of these sources as rifting continues.

62 The mafic lavas and dikes of continental rift margins provide a window on the evolution of

63 the underlying mantle sources that have contributed to a developing rift. Unfortunately, most

64 rifted margins are now at least partly submarine and relatively inaccessible. However, sustained

65 uplift above an active mantle plume in Ethiopia has provided a sub-aerial instance of a

66 continental rift margin in the final stages of its evolution. Observations around the Afar triple-rift

67 junction confirm that magmatic intrusion and crustal heating have played a significant role in 
68 facilitating lithospheric extension and rupture (Berckhemer et al., 1975; Mohr, 1983a; Buck,

69 2004; Buck, 2006; Bialas et al., 2010; Bastow and Keir, 2011). The western margin of Afar

70 provides an excellent site for probing the space-time relationships between magmatism and

71 extension across a rift margin (e.g., Keir et al., 2011b). In this paper we examine the

72 geochemical, structural, and geochronological properties of the dikes that intrude this continental

73 margin, and explore the participation of the various mantle and lithospheric geochemical

74 reservoirs that contribute to the evolution of this margin.

\section{The Western Afar Rift Margin}

$77 \quad 2.1$ Setting and Form

The well-studied western Afar margin separates the stable and relatively undeformed

79 post-basement cover of the Ethiopian Plateau to the west from the Cenozoic and presently active

80 extensional faulting, fissuring, and magmatism of the Afar depression (Gortani and Bianchi,

81 1937; Abbate et al., 1968; Abbate and Sagri, 1969; Mohr, 1971; Megrue et al., 1972; Gortani and

82 Bianchi, 1973; Justin-Visentin and Zanettin, 1974; Mohr, 1983a; Hart et al., 1989; Wolfenden et

83 al., 2005). The 800-km long western Afar margin runs in a gently curvilinear plan from Asmara

84 in the north to Addis Ababa in the south, with the exception of a large dextral offset at latitude

$8513^{\circ} \mathrm{N}$ (Fig. 1). This coincides with the northern limit of the thick flood-lava sequence on the

86 plateau, and also marks a structural contrast: to the north, seismically active stepped normal

87 faults downthrown towards the rift are concentrated within a narrower margin (40 km); to the

88 south, antithetically faulted flood-basalts cap a wider $(80 \mathrm{~km})$ monoclinal margin (Mohr, 1962;

89 Abbate and Sagri, 1969; Ayele et al., 2007; Keir et al., 2011a). This southern sector of the

90 margin can in turn be divided into two sub-sectors to either side of a proposed accommodation 
91 zone (Wolfenden et al., 2005). North of latitude $11^{\circ} \mathrm{N}$, the flood-basalt pile comprises 31-29 Ma

92 lavas and tuffs locally overlain by a cover of $\sim 25-22$ Ma flows (Justin-Visentin and Zanettin,

93 1974; Kieffer et al., 2004). Proceeding south from $11^{\circ} \mathrm{N}$ to Addis Ababa, the Oligocene flood-

94 basalt pile is capped by progressively younger lavas that include a volumetrically significant

95 proportion of silicic members (Zanettin, 1992; Ukstins et al., 2002). The margin transect chosen

96 for this study is located immediately north of the chronological divide at $11^{\circ} \mathrm{N}$ (Fig. 1), taking

97 advantage of the Desse-Eloa highway (Mohr, 1971; Gortani and Bianchi, 1973).

98

99 2.2. Regional Stratigraphy

100 Expanding upon earlier studies detailing the stratigraphic and structural characteristics of

101 the western Afar margin (Abbate et al., 1968; Gortani and Bianchi, 1973; Justin-Visentin and

102 Zanettin, 1974; Mohr, 1983b), a new stratigraphy for the entire southern sector of the western

103 Afar margin has been compiled by Wolfenden et al., (2005). It comprises four magmatic

104 episodes (Table 1) which relate to a sequential, riftward production of three elongate rift-parallel

105 volcanic basins imposed on the regional Oligocene flood-basalt pile:

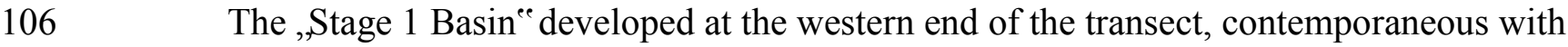

107 eruption of basalts and agglomerates derived from the 25-22 Ma-old Guguftu shield volcano

108 located on the plateau rim (Kieffer et al., 2004). These Dese Formation lava flows are rarely

109 more than a few meters thick, and lie with local unconformity on the lateritized and strongly

110 zeolitised Oligocene pile. Characteristic lithologies are megacrystic plagioclase basalt, aphyric

111 basalt, and subordinate olivine- and olivine-augite-phyric basalt. The pyroclastic members

112 include fine basaltic tuff (in one instance carrying blocks of underlying, unexposed Jurassic

113 limestone) and massive agglomerate proximate to basalt pipe vents. Silicic ash-fall and ash-flow 
114 tuff beds are restricted to the topmost part of the Dese Formation. The ,Stage 2 Basin ${ }^{\text {ee }}$ is situated

115 near the median of the Desse-Eloa transect. Its fill of flood basalts and intercalated ignimbrites

116 compose the early-mid Miocene Burka Formation (Wolfenden et al., 2005), again lying with

117 unconformity on the Oligocene stratoid pile. The „Stage 3 Basin ${ }^{e e}$ at the eastern end of the

118 transect contains the late Miocene-Pliocene Dahla Series basalts, previously termed Fursa

119 Basalts (Justin-Visentin and Zanettin, 1974).

120

121 2.3. Dikes and faults of the Desse - Eloa transect

122 Antithetic faulting parallel to the NNW regional strike of the margin has produced tilted 123 crustal blocks typically 10-20 km across (Abbate and Sagri, 1969; Mohr, 1983b). The resultant

124 dips of the Oligocene stratoid pile average $20^{\circ}-30^{\circ}$ in the west sector of the transect, $15^{\circ}-30^{\circ}$ in 125 the central sector, and $15^{\circ}-20^{\circ}$ in the east (Table 2). However, occasional deep gorge exposures 126 reveal maximum dips of $30^{\circ}$ in the west and $45^{\circ}$ in the east, indicative of second-generation 127 block faulting (Morton and Black, 1975). Fault-plane dip is directed overwhelmingly westward, 128 and averages $80^{\circ}$ in the western sector. Common $70^{\circ}$ dips in the central and eastern sectors are 129 interspersed with local $35^{\circ}-45^{\circ}$ dips. The predominating margin-parallel faults can number up to 130 forty within a kilometre-wide zone, the largest with measured throws in excess of one hundred 131 metres, the majority with west-side downthrows. Subordinate faults oblique to the regional trend 132 include N-dipping ENE faults (yielding a southerly component of dip to the stratoid pile), S-

133 dipping WNW faults, and W-dipping NNE faults (Mohr, 1971). Striations on some fault planes 134 prove a component of lateral slip. Small sinusoidal folds with ENE-trending axes are pervasive 135 in some areas. 
Nearly 80 percent of all dikes strike parallel or near-parallel to the dominant NNW-

137 trending faults that define the margin. The oblique strikes of a minority of dikes are mirrored by

138 subordinate fault trends (Table 2). However, while dikes and faults share common conjugate

139 trends within the western Afar margin (Abbate and Sagri, 1969; Mohr, 1971; Justin-Visentin and

140 Zanettin, 1974; Mohr, 1983b), the major zones of fissuring and fracturing are separate and rarely

141 overlap. The tendency to spatial segregation of fault zones and dike swarms in the western Afar

142 margin may owe not only to temporal separation of the two processes in an evolving stress field,

143 but also to the role, as yet not fully evaluated, of magmatic centres from which dikes were

144 laterally propagated. The longest exposed dike identified in the transect is almost one kilometre,

145 but a consideration of dikes elsewhere in Ethiopia makes it likely that some may extend for at

146 least $10 \mathrm{~km}$ (Mohr, 1999; Schultz et al., 2008). The median dike width over the entire Desse-

147 Eloa transect is $1.5 \mathrm{~m}$, with a mean of $3.5 \mathrm{~m}$ (Mohr, 1971, 1983b).

148 Dike distribution across the Desse-Eloa transect is irregular (Mohr, 1971, Fig. 1), in part

149 influenced by local volcanic centres to north and south. At the western plateau end of the

150 transect, between Desse $(2525 \mathrm{~m})$ and Combolcha $(1875 \mathrm{~m})$, a pattern of Oligo-Miocene

151 antithetic faulting trending N-NNW (now largely masked under Miocene Guguftu volcanics)

152 has been superposed with complex Quaternary marginal graben faulting (Mohr, 1962). Near

153 Dessie, Oligo-Miocene fault-blocks are tilted $10-30^{\circ}$ (rarely as steeply as $45^{\circ}$ ) directed between

154 E and NE, whereas near Combolcia tilts of $20-30^{\circ}$ are directed between $\mathrm{E}$ and SE. The dikes

155 exposed in this sector relate almost wholly to the covering Guguftu volcanic sequence, and trend

156 N-S, slightly oblique to the NNW-SSE regional structural trend. Dike dips range between $60^{\circ}$

157 and vertical, directed west as for the major faults (Mohr, 1971; Mohr, 1983b). Subordinate dikes

158 trending ENE persist further eastward into the central sector of the transect. 
The descent east from Combolcha and the Ancharo rim of the Borkenna graben (Fig. 1)

160 reaches a NNW-SSE zone of intense faulting in the Chaleka valley $(1520 \mathrm{~m})$ (Abbate \& Sagri,

161 1969). Through this sector of the traverse, riftward-tilted blocks of lateritized, zeolitized

162 Oligocene flood-basalts locally manifest small sinusoidal folds also found in the Desse-

163 Combolcia sector. Feeder dikes for the lavas are mostly in 3-D parallelism with the regional

164 NNW-trending faults, and strike towards the Ardibbo volcanic centre, $40 \mathrm{~km}$ to the north. Large

165 (<35 m-wide) feeder pipes also occur, ringed with precursor, intensely baked agglomerate.

166 Subordinate dikes of ESE trend (SW dip) and NNE trend (W dip) can form a symmetrical

167 complementary pair about the dominant NNW dikes. If synchronous, they indicate a maximum

168 principal horizontal stress directed along the strike of the margin (Mohr, 1971), concurring with

169 the geometry of the folds and some small reversed faults in the flood-basalt pile.

170 From the Chaleka valley east up to the Batie saddle $(1670 \mathrm{~m})$, interspersed NNW and

171 NNE-trending dikes expose no cross-cutting relationships. Some NNW dikes became normal slip

172 planes during solidification, but others were subject to later oblique, brittle displacement. For

173 example, intrusion EKA-119, a 6 m-wide, near-vertical N300 dike was displaced by a N030

174 fault dipping $75^{\circ} \mathrm{SE}$, the 3-D orientation of neighbouring NNE dikes.

175 Down the eastern slope of the Batie saddle, the transect declines rapidly to Wadi Burca

$176(1000 \mathrm{~m})$, then more gently onto the Enelu plain $(950 \mathrm{~m})$. From the eastern side of the plain

177 (Wadi Fursa), the decline resumes to Eloa $(675 \mathrm{~m})$ at the western edge of the Afar floor (Fig. 1).

178 Between 4 and $8 \mathrm{~km}$ east of Batie, both dikes and faults are numerous and share a NNE trend

179 distinctly oblique to the regional margin trend. The maximum measured dilatation for the entire

180 Desse-Eloa transect occurs here: a total dike width of $60 \mathrm{~m}$ opened within a $1 \mathrm{~km}$-wide crustal

181 strip, indicating 6\% extension. East from this swarm for $15 \mathrm{~km}$, limited exposures of tilted 
182 Oligocene flood-basalts in the Burca valley (,Stage 2 Basin of Wolfenden et al., 2005) reveal 183 rare thin, fractured dikes, until more typical dikes resume in the Fursa valley (,Stage 3 Basin of

184 Wolfenden et al., 2005).

185

\section{3. Analytical Techniques}

187 Dikes in preference to lavas have been selected for this study, as they form in response to both 188 the structural and magmatic evolution of the margin. Furthermore, flood basalt lavas can flow 189 significant distances from their vents, thus potentially skewing spatial studies.

$190 \quad 3.1$ Geochronology

191 Ten representative samples that did not exhibit any indications of alteration were selected

192 for ${ }^{40} \mathrm{Ar}-{ }^{39} \mathrm{Ar}$ step heating analysis at the Argon Geochronology Laboratory at the University of 193 Michigan. Fresh matrix chips (0.2g) were carefully handpicked under a binocular microscope 194 and Ar analysis was undertaken using standard procedures outlined in Frey et al., (2007).

195 Samples were wrapped in pure Al foil packets and irradiated in location 5C of the McMaster 196 Nuclear Reactor. Samples were step-heated using a continuous 5W Ar-ion laser and Ar isotopes 197 were analyzed using a VG-1200S mass spectrometer operating with a total electron emission 198 setting of 150 micro-amps (see Table 3 and supplemental table for further analytical 199 information).

2013.2 Major and Trace elements.

202 Thirty-five samples (1-2 kg) were taken from the least-altered dikes, and for each dike 203 from a position intermediate between the centre and margin. They were subsequently trimmed to 204 exclude visible alteration/weathering. Sample billets were polished to remove saw marks and 
205 cleaned in an ultra sonic bath with deionised water. After drying, the billets were crushed in a

206 steel jaw-crusher and then powdered in a ceramic Bico flat plate grinder. The sample powders

207 were fused into lithium tetraborate glass disks using the procedures outlined in Deering et al., 208 (2008). Major elements, Zr, Sr, Rb and Ni were analyzed by Brucker XRF, the balance of the

209 trace elements were obtained by laser-ablation using a Cetac LSX-200 coupled to a Micromass

210 Platform ICP-MS at Michigan State University. Trace element reproducibility based on standard

211 analyses (see supplemental data) is typically better than 5\% (Vogel et al., 2006).

$213 \quad 3.3$ Isotope Geochemistry

214 Twelve representative samples of the western Afar dikes were chosen for radiogenic 215 isotope analysis at the Laboratoire Domaines Océaniques of CNRS/ Ifremer, France. Samples 216 were chosen on the basis of a) representing all dike groups, and b) selecting the most primitive 217 magmas possible. Powdered samples (300 to $600 \mathrm{mg}$ ) were dissolved in Savillex beakers using 218 ultrapure concentrated $\mathrm{HF}-\mathrm{HBr}$ (3:1 in volume). Separation and analyses of $\mathrm{Pb}, \mathrm{Hf}, \mathrm{Sr}$ and $\mathrm{Nd}$ 219 were performed from the same sample dissolution using 4 different columns.

220 Column 1 : to minimize $\mathrm{Pb}$ blanks, $\mathrm{Pb}$ separation was performed first, using the standard 221 anion exchange method in an HBr medium (Tilton, 1973; Manhes et al., 1978). After loading the 222 sample, the $\mathrm{Pb}$ column was washed with $0.5 \mathrm{M} \mathrm{HBr}$. The fraction passing through the column 223 directly following loading and subsequent washing was collected and evaporated in $6 \mathrm{M} \mathrm{HCl} \mathrm{for}$ 224 further separation of Hf-Sr-Nd on column 2. We repeated the anion exchange method a second 225 time to purify the $\mathrm{Pb}$ fraction which was collected in $6 \mathrm{M} \mathrm{HCl}$.

226 Column 2 : the Hf-Sr-Nd fraction was taken up in $0.5 \mathrm{M} \mathrm{HCl} / 0.15 \mathrm{M}$ HF and loaded on a 227 cation column (microcolumn Savillex, 30 ml, $6.4 \mathrm{~mm}$ ID x $9.6 \mathrm{~mm}$ OD x $25 \mathrm{~cm}$ ). The Hf-Ti 
228 fraction was eluted in the first $6 \mathrm{ml}$ with $0.5 \mathrm{M} \mathrm{HCl} / 0.15 \mathrm{M} \mathrm{HF} .22 \mathrm{ml}$ of $3 \mathrm{M} \mathrm{HCl}$ was then

229 added to the column to wash for $\mathrm{Fe}$ and $\mathrm{Rb}$, and the $\mathrm{Sr}$ fraction was then collected in $6 \mathrm{ml}$ and

230 evaporated to dryness. $8 \mathrm{ml}$ of $4 \mathrm{M} \mathrm{HNO}_{3}$ was then added to the same column to separate $\mathrm{Ba}$ from

231 the rare earth elements, which were then recovered in a $6 \mathrm{ml}$ fraction.

232 Column 3 : following evaporation, the rare earth fraction was placed on a Biorad Econo-

233 Col Polyprop $0.8 \mathrm{~cm}$ x $4 \mathrm{~cm}$ loaded with Eichrom LN resin. Nd was separated from Ce and Sm

234 using $13 \mathrm{ml}$ of $0.2 \mathrm{M} \mathrm{HCl}$ and eluted using $4 \mathrm{ml}$ of $0.35 \mathrm{M} \mathrm{HCl}$.

235 Column 4 : the Hf-Ti fraction separated using column 2 is evaporated and taken up in 6

$236 \mathrm{M} \mathrm{HCl}$ containing a trace of $\mathrm{H}_{2} \mathrm{O}_{2}$. The Hf-Ti separation was performed using a $5 \mathrm{ml}$ pipette tip

237 loaded with $100 \mathrm{mg}$ of Eichrom $\mathrm{LN}$ resin that was washed with $6 \mathrm{M} \mathrm{HCl} .10 \mathrm{ml} 6 \mathrm{M} \mathrm{HCl}$ with

$23850 \mu \mathrm{l}$ of $\mathrm{H}_{2} \mathrm{O}_{2}$ were used to elute Ti. Hf was subsequently collected in $5 \mathrm{ml}$ of $2 \mathrm{M} \mathrm{HF}$.

$239 \mathrm{~Pb}, \mathrm{Nd}$, and $\mathrm{Hf}$ were analyzed by MC-ICPMS on the Thermo Neptune at Ifremer. Sr was

240 analyzed by TIMS using the Finnigan MAT-26X also located at Ifremer. Standards, blanks and

241 analytical errors are given in the caption to Table 4.

242

\section{4. Results and classification of dikes}

$244 \quad 4.1$ Geochronology

245 4.1.1 Cross-cutting relationships

246 Pervasive zeolitisation of the Oligocene stratoid lavas, and to a lesser extent their feeder

247 dikes, was accomplished before intrusion of the 25-22 Ma-old Guguftu dikes, consistent with

248 the expected thermal history of a 1 km-thick lava pile (Walker, 1960; Jepsen and Athearn, 1962).

249 The essentially perpendicular relationship of the flood basalt lavas to the great majority of dikes

250 indicates that ratchet faulting and block tilting of the lava pile occurred after fissuring and 
251 magmatic injection was largely accomplished. Nevertheless, in some cases the time interval

252 between fissuring faulting was brief, as evidenced by ductile deformation along dike axes.

253 Young intra-margin faulting is exemplified in a 12 Ma-old dike (EKA-119 on the Batie saddle)

254 displaced by a NNE-trending fault. In general, however, field studies across the western Afar

255 margin are not yet sufficient to distinguish the relative age-relationships among the several

256 trends of dikes and faults.

$257 \quad 4.1 .2^{40} \mathrm{Ar}{ }^{39} \mathrm{Ar}$ dating

258 The results of the ${ }^{40} \mathrm{Ar} /{ }^{39} \mathrm{Ar}$ analyses are shown in Table 3. Replicate analyses were 259 performed for each sample and a series of ${ }^{40} \mathrm{Ar} /{ }^{39} \mathrm{Ar}$ model ages were calculated. Sample EAD-

260111 yielded plateau ages for both of the analyses that were performed, but there were also signs 261 of a "saddle" shape to the age spectrum, suggesting a small quantity of excess ${ }^{40} \mathrm{Ar}$. The

262 combined isochron age (CIA) is based on a true isochron through all 26 gas fractions with a 263 slightly elevated initial ${ }^{40} \mathrm{Ar} /{ }^{36} \mathrm{Ar}$ ratio of 298.5 Although the CIA is not significantly different 264 from the average of the error weighted plateau age (EWP) values, we consider the CIA to be the 265 preferred age $(23.57 \mathrm{Ma})$ for this sample, because the EWP values may be slightly biased to an 266 erroneously high age.

267 For sample EAD-114, there are no EWP segments and there are definite signs of ${ }^{40} \mathrm{Ar}$ 268 loss in the lowest temperature fractions. In addition, there is a monotonic decrease in apparent 269 ages with increasing release temperatures, which suggests that there was internal redistribution 270 of ${ }^{39} \mathrm{Ar}$ due to recoil. Therefore, we regard the average of the reduced integrated ages (RIA) ages 271 to be the preferred age for this unit (24.76 Ma). In contrast, sample EKA-112B has EWP values 272 over the entire age spectrum for both replicates. All four model ages agree within error and given 
273 that there is no sign of significant Ar loss or artifacts due to recoil, the average EWP value is our 274 preferred age for this sample (30.77 Ma).

275 Three replicate analyses were performed for sample EKA-116 and the age spectra show 276 definite signs of Ar loss in the low temperature fractions, probably due to alteration minerals.

277 Nonetheless, all three samples had EWP segments, indicating relatively good Ar retention for the 278 higher temperature gas fractions. However, there is a nearly monotonic decline in ages with 279 increasing release temperatures, suggesting the possibility for recoil artifacts. Therefore, we 280 prefer the average of RIA (29.78 Ma), which avoids the Ar-loss portions of the age spectra, but 281 correctly accounts for the possibility of internal redistribution of ${ }^{39} \mathrm{Ar}$ from recoil.

283 segments. However, there are definite signs of a "saddle" shape, which suggests the possibility

284 of excess ${ }^{40} \mathrm{Ar}$. In order to minimize the possibility of having a bias to high ages, we prefer the 285 CIA age through 37 gas fractions, which yields an "errorchron" with an initial ${ }^{40} \mathrm{Ar} /{ }^{36} \mathrm{Ar}$ value of 286297.7 and an age that is only slightly older than the average EWP age $(12.51 \mathrm{Ma})$. For sample 287 EKA-120, only two of the three analyses yielded EWP segments and because of significant 288 apparent age variations that correspond with changes in the $\mathrm{Ca} / \mathrm{K}$ ratio, we regard the average 289 RIA age to be the most reliable age estimate (27.37 Ma).

290 Sample EKA-140A exhibited rather poor reproducibility and only one of the two 291 analyses gave an EWP segment. The age of this sample is not well constrained, but we consider 292 that the average RIA value is the best estimate for the age of this unit (8.31 Ma). For sample 293 EKA-153, there are signs of significant Ar loss in the low temperature gas fractions and given 294 that there are no plateau segments, the RIA average is likely to be the best date for this sample 295 (20.55 Ma). 
Table 3 also shows K-Ar ages derived from the data in Megrue et al. (1972), with ages

297 being updated to the decay and K composition constants in Steiger and Jäger (1977) and error

298 estimates based upon the listed error estimates for $\mathrm{K}$ and ${ }^{40} \mathrm{Ar}^{*}$. For samples EAD-111 and EAD-

299114 , there is very good concordance between our Ar-Ar ages and the K-Ar ages in Megrue et al.

300 (1972). For all of the other samples, the K-Ar ages are systematically higher than the Ar-Ar ages,

301 although in most cases, this difference is only slightly larger than the error estimate in the K-Ar

302 age. It is possible that the K-Ar ages are biased high because of the presence of excess Ar, a

303 common problem with dike samples. Even though some host rock samples in Megrue et al.,

304 (1972) show ages that are greater than the dike ages, Hyodo and York (1993) showed that it is

305 possible for an excess Ar "wave" to propagate from a dike and contaminate hosting rock. Care

306 must be taken when interpreting K-Ar data that does not have the detail that is shown in Ar-Ar

307 age spectra. Sample EKA-140A gives an ${ }^{40} \mathrm{Ar} /{ }^{39} \mathrm{Ar}$ age which is less than half than the K-Ar age

308 in Megrue et al., (1972), too great an age difference to be explained by excess Ar and probably

309 due to separate samplings from two intimate populations of dikes at this locality.

311 4.2 Major and Trace Element Geochemistry

312 On the basis of their trace element geochemistry (see supplemental data tables), the dikes

313 of the western Afar margin at latitude $11^{\circ} \mathrm{N}$ can be divided into four groups.

315 4.2.1 Groups 1 and 2 dikes $(21-27 \mathrm{Ma})$.

316 Group 1 dikes ( 30-27 Ma) are ankaramitic dolerites. They strike NNE and are

317 concentrated in the eastern part of the Combolcha-Batie sector. They are chemically defined by

318 lower REE in comparison to other groups, particularly for LREE, and low LREE/HREE ratios 
319 that lead to an overall less steep REE profile (Fig. 2). Low concentrations characterize the

320 extended trace-element plot, with diagnostic peaks for $\mathrm{Pb}, \mathrm{Sr}$ and to a lesser extent, $\mathrm{K}$ (Fig. 3).

321 On the basis of geochemistry, the Ethiopian (or Western) plateau has been divided into separate

322 high- and low-titanium (HT and LT) domains (Pik et al., 1998). While this study lies well within

323 the HT domain, Group 1 dikes have a geochemical signature that broadly resembles that of the

324 earliest, low-titanium (LT) Ethiopian Plateau flood basalts (Kieffer et al., 2004; Beccaluva et al.,

325 2009). Major element variation diagrams for Group 1 dolerites and LT basalts typically overlap,

326 though $\mathrm{Al}_{2} \mathrm{O}_{3}$ is significantly lower and $\mathrm{TiO}_{2}$ slightly elevated in the dolerites (Fig. 4a).

327 Likewise, primitive mantle-normalized diagrams show that Group 1 dolerites and LT basalts

328 exhibit very similar trace element patterns, excepting dike EKA-120, an augite-hyaloankaramite

329 with slightly higher values of $\mathrm{Nb}$, Ta and $\mathrm{Sr}$ (Fig. 3). The more incompatible trace elements,

330 however, are enriched in the Group 1 dolerites with respect to LT basalts of equivalent $\mathrm{MgO}$

331 content (Fig. 3).

332 Group 2 dikes ( $\sim 31 \mathrm{Ma})$ occur spread across the Combolcha-Batie sector. These

333 plagioclase-rich dolerites are distinguished by steep REE profiles and the highest $\mathrm{La} / \mathrm{Yb}_{\mathrm{CN}}$ (up to

334 11.5) of all the Afar margin dikes. Extended trace element profiles of Group 2 dolerites have

335 features in common with Ethiopian Plateau group 1 high-titanium flood basalts (HT-1), notably

336 troughs for Th- $\mathrm{U}$ and $\mathrm{P}$, and peaks for $\mathrm{Ba}$ and $\mathrm{Nb}-\mathrm{Ta}$ (Fig. 3), consistent with the study region

337 lying within the HT province (e.g. Pik et al., 1998). Group 2 and HT-1 samples also exhibit

338 similar element-MgO plots (Fig. 4a), excepting elevated $\mathrm{Sr}$ in the dolerites that is independent of

$339 \mathrm{CaO}$ (not shown). Group 2 dolerites and HT-1 basalts are distinguished from Group 2 high-

340 titanium flood basalts (HT-2) which have more elevated $\mathrm{TiO}_{2}$ (Fig. 4a) and more depleted

341 HREE. 


\section{4.2.2 Group 3 dikes $(<10 \mathrm{Ma})$}

344 Group 3 dikes are restricted to the swarm east of Batie. Group 3 and Group 1 dolerites

345 share flat REE profiles, but the former are distinguished by higher concentrations of trace

346 elements, excepting depletions in Sr, Eu and Ti (Fig. 3). Three basalt lava flows sampled by Hart

347 et al., (1989) from locations between Wadi Fursa and Batie, have similar trace element

348 characteristics to our Group 3 dolerites from the same area. Compared with Quaternary basaltic

349 lavas from the Ethiopian rift valley (Fig. 4b), Group 3 dolerites display low $\mathrm{Al}_{2} \mathrm{O}_{3}$. They show a

350 closer match with the major element range defined by Djibouti Holocene basaltic lavas (Deniel

351 et al., 1994), a match which extends to trace element abundances (Fig. 4b), especially for recent

352 Asal Rift lavas (Deniel et al., 1994), excepting that Group 3 dolerites are more enriched in

353 HREE. The broad geochemical similarities between the Group 3 dolerites and Quaternary Afar

354 and Ethiopian rift basalts link to their significantly younger age compared with the Groups 1 and

3552 dolerites (Hart et al., 1989; this study).

$357 \quad 4.2 .3$ Group 4 dikes ( 25-12 Ma)

358 Group 4 dikes occur across the entire width of the western Afar margin at latitude $11^{\circ} \mathrm{N}$.

359 They encompass all dolerites that exhibit REE slopes intermediate between those of Groups 2

360 and 3 (Fig. 2). Whilst extended trace element patterns for Group 4 dolerites are broadly similar to

361 Groups 2 and 3, REE slopes are less pronounced in comparison with Group 2 samples (Fig. 2).

362 Matching their intermediate REE characteristics, Group 4 dolerites fall chronologically between

363 Groups 2 and $3(\sim 25-12 \mathrm{Ma})$. Two subdivisions of Group 4 are identified: REE, Ti and Y

364 abundances are higher in Group 4a dolerites compared with Group 4b (Figs. 2; 3; 4c). Group 4a 
365 dolerites were intruded during the period 20-12 Ma across the greater part of the margin. The

366 timing coincides with the $19-11$ Ma syn-extensional Getra Kele basalts from southern Ethiopia

367 (George and Rogers, 2002). In contrast, Group 4b dikes yield ages clustered around $24 \mathrm{Ma}$ and

368 are restricted to the Desse-Combolcha sector. These dikes are considered to be feeders for the

369 earlier lavas of the $22-25$ Ma Guguftu shield volcano (Kieffer et al., 2004). Two isolated Group

$3704 \mathrm{~b}$ dikes intruded east of Batie: mingled dolerite EKA-128, and evolved alkali trachyte EKA-

$371 \quad 134$.

372

373 4.3. Isotope Geochemistry

374 Twelve representative dolerites spanning the five chemical groups were selected for

375 isotopic analysis (Table 4). The data plot within a three end-member mixing space defined by 376 depleted mantle, Pan African lithosphere and the Afar plume mantle, as identified in studies of

377 Quaternary basalts in Afar and the Ethiopian rift, and Gulf of Aden (Hart et al., 1989; Schilling

378 et al., 1992; Deniel et al., 1994; Trua et al., 1999; Furman et al., 2006; Rooney et al., 2012a).

$380 \quad$ 4.3.1 Groups 1 and 2 dikes

381 Group 1 have more radiogenic $\mathrm{Pb}$ isotopic compositions than the LT basaltic flows, and 382 plot close to the "C" mantle reservoir (Hanan \& Graham 1996; Fig. 5). However, other isotopic 383 systems ( $\mathrm{Sr}, \mathrm{Nd}$ and $\mathrm{Hf}$ ) are not consistent with a simple derivation from this single mantle 384 reservoir (Fig. 6, 7, 8). In contrast, our single analyzed Group 2 sample, ankaramite sill EKA385 112B, exhibits less radiogenic $\mathrm{Pb}$ isotopes that have elevated ${ }^{207} \mathrm{~Pb} /{ }^{204} \mathrm{~Pb}$ and ${ }^{208} \mathrm{~Pb} /{ }^{204} \mathrm{~Pb}$ at a 386 given ${ }^{206} \mathrm{~Pb} /{ }^{204} \mathrm{~Pb}$ in comparison with $\mathrm{HT}-1$ basalts from this region. These isotopic parameters 
387 do, however, plot consistently within the fields defined for Oligocene magmatism in Yemen

388 (e.g., Baker et al., 1996a).

390 4.3.2 Group 3 dikes

391 Group 3 dolerites have the most radiogenic $\varepsilon_{\mathrm{Hf}}$ and $\varepsilon_{\mathrm{Nd}}$ (Fig. 7), and least radiogenic $\mathrm{Sr}$

392 (Fig. 6) and ${ }^{207} \mathrm{~Pb} /{ }^{204} \mathrm{~Pb}$ (Fig. 5) of all the samples analyzed in this study. The $\mathrm{Pb}$ isotope values

393 overlap with those of the least radiogenic Quaternary Ethiopian rift basalts (Fig. 5), but Sr is

394 significantly less radiogenic (Fig. 6) while $\mathrm{Hf}$ and $\mathrm{Nd}$ are more radiogenic (Fig. 7). These

395 features link Group 3 dolerites to Djibouti and axial Gulf of Aden basalts. Western Afar margin

396 basalts of similar age-range to the Group 3 dolerites, analyzed by previous authors (Hart et al.,

397 1989), share common trace-element characteristics. However, these basalts exhibit less-

398 radiogenic $\mathrm{Pb}$ isotopic signatures and typically form a broad trend, indicating the influence of

399 the lithosphere on the erupted compositions (Fig. 5).

400

\subsubsection{Group 4 dikes}

402 Group 4 dolerites form an array in $\mathrm{Pb}$-isotope space that indicates a substantial 403 compositional heterogeneity between radiogenic and unradiogenic components (Fig. 5). The

404 unradiogenic $\mathrm{Pb}$ component correlates with unradiogenic $\mathrm{Nd}$ and radiogenic $\mathrm{Sr}$, interpreted here 405 as Pan-African lithosphere. Group 4a dolerites overlap with, but do not extend to more 406 radiogenic ${ }^{206} \mathrm{~Pb} /{ }^{204} \mathrm{~Pb}$ compositions (Fig. 5) displayed by the contemporaneous Getra Kele 407 basalts in southern Ethiopia (Stewart and Rogers, 1996; George and Rogers, 2002). Indeed, 408 substantial heterogeneity is evident between the two, where the radiogenic end-member of the 
409 Getra Kele Formation appears HIMU-like (George \& Rogers, 2002), distinct from the "C"

410 signature of the Afar plume present in all dike groups from the western Afar margin.

\section{5. Discussion}

4135.1 Revised chronostratigraphy for the Desse-Eloa traverse.

414 The present study adds geochronological constraints to the existing stratigraphic record 415 outlined for the western Afar margin at latitude $11^{\circ} \mathrm{N}$ (Table 1). We confirm that magmatic 416 activity in the region commenced with voluminous fissure- and pipe-fed basalt eruptions $\sim 31 \mathrm{Ma}$ 417 ago (Hofmann et al., 1997; Ukstins et al., 2002). The feeders for this pile comprise our Group 2 418 dolerites. Group 1 ankaramitic dikes are coincident with a period of major crustal extension and 419 block faulting that followed the emplacement of the thick lava pile. Between 25 and $22 \mathrm{Ma}$, a 420 period of localized magmatic activity is represented by closely spaced Group $4 \mathrm{~b}$ dikes, feeders to 421 the Guguftu Formation basalts (Ukstins et al., 2002; Kieffer et al., 2004) which flowed from the 422 plateau rim down into a small „Stage $1^{\text {" }}$ basin (Wolfenden et al., 2005).

423 Between 20 and $12 \mathrm{Ma}$, a third magmatic episode produced the Burka Formation basalts, 424 ignimbrites and tuffs (Walter, 1980; Wolfenden et al., 2005) that accumulated in a ,Stage $2^{\text {ce }}$ 425 basin immediately east of Batie. While the geochemistry of our Group 4a dikes matches that of 426 the Burka formation basalts, these dikes occur over a wider region than Wolfenden et al." $\mathrm{s}$ 427 (2005) basin. The fourth and final magmatic episode within the Desse-Eloa transect produced the 428 Upper Miocene Fursa basalts (Justin-Visentin and Zanettin, 1974). Renamed the Dahla Series by 429 Wolfenden et al. (2005), they accumulated in a „Stage $3^{\text {ee }}$ basin at the eastern end of the transect. 430 Wolfenden et al. (2005) assign a period of 6.6-5.3 Ma to this series, but this activity may extend 431 back to $10 \mathrm{Ma}$ (Walter, 1980; Hart et al., 1989; Deniel et al., 1994). These lavas were fed by our 
432 Group 3 dikes which, however, are located in the central sector of the transect somewhat to the 433 west of the ,Stage $3^{\text {ee }}$ basin.

435 5.2 Magmatic Processes along the Western Afar margin

436 The five magmatic groups defined along the western Afar margin are distinct in terms of

437 REE patterns, and the origin of these patterns reflects magmatic processes active during the 438 evolution of the Afar rift margin. To more effectively illustrate these distinctions we have 439 undertaken a principal components analysis of the dolerite REE data. We have used a log440 centered transform technique to overcome the constant sum constraint inherent to this form of 441 statistical analysis (Aitchison, 1986).

$$
\mathrm{Z}_{\mathrm{i}}=\log \left(\mathrm{X}_{\mathrm{i}} / g\left(\mathrm{X}_{\mathrm{D}}\right)\right.
$$

443 where: $g\left(\mathrm{X}_{\mathrm{D}}\right)$ is the geometric mean of all elements of interest

449 Approximately $96 \%$ of the variance is accounted for within the plane of the first two 450 eigenvectors, and this increases to $97.8 \%$ with the addition of the third eigenvector. The first 451 principal component (PC-1) is most influenced by the LREE and HREE, with less control from 452 the MREE (Table 5), whereas the second principal component (PC-2) is dominantly influenced 453 by LREEs and MREE (Fig. 9). The third principal component (PC-3) is dominated by Eu, Tb 454 and Ce and represents anomalous enrichments or depletions in these elements (e.g. plagioclase- 
455 related Eu anomaly) not accounted for by PC-1 and 2. To assess the root cause of these

456 variations, we explore the various processes that may impact on the REE patterns.

457 To a first order, fractional crystallization of nominally anhydrous mafic gabbroic

458 assemblages and assimilation of continental crust will elevate the LREE/HREE values in an

459 evolving magma. PC-1 is sensitive to LREE and HREE variations and exhibits clear correlation

460 with $\mathrm{MgO}$, increasing sharply for groups 2 and 3 at $\sim 5 \% \mathrm{MgO}$ (see supplemental data), though

461 no clear correlation is evident for groups $4 \mathrm{a}$ and $4 \mathrm{~b}$. These data may be interpreted to infer that

462 below $\sim 5 \% \mathrm{MgO}$, lithospheric assimilation and fractional crystallization processes control the

463 REE behavior of these magmas. For this reason, interpretations of potential mantle processes are 464 confined to dolerites with $>5 \% \mathrm{MgO}$. This minimizes (but does not eliminate) the influence of

465 gabbroic fractionation, lithospheric assimilation (Peate et al., 2008), and the complicating effects 466 of REE-enriched phases that may become saturated in more evolved magmas (e.g. apatite and 467 titanite: Bachmann and Bergantz, 2008).

468 Variability in the source and degree of melting are the dominant causes of REE

469 heterogeneity in more primitive magmas. In a continental rifting environment, the lithospheric

470 thickness determines the upper limit of the mantle melting column (Wang et al., 2002).

471 Decreasing lithospheric thickness means a relative increase in melt from the shallower spinel

472 lherzolite zone and relatively less melt from the deeper garnet lherzolite zone with a concomitant

473 change in the MREE/HREE ratios of resulting magmas. Whilst lithospheric thinning may be an

474 important ongoing process in southern and central Ethiopia (Rooney, 2010; Rooney et al., 2011),

475 for the northern Ethiopian rift, located above the center of the ascending Oligocene plume head

476 (Beccaluva et al., 2009), studies of temporal variation of lithospheric thickness have shown that 
477 substantial thinning must have occurred prior to or contemporaneous with the initial flood basalt

478 event (Ayalew and Gibson, 2009).

479 In a plume-influenced environment, variable contributions from ambient upper mantle

480 and the potentially diverse components hosted within the upwelling plume may have a

481 significant impact on the trace element characteristics of resulting magmas. A temporal decrease

482 in plume contribution (and a concomitant increase in role of the depleted upper mantle) should

483 correspond to source depletion and a decrease in LREE/HREE (Schilling, 1973). On the other

484 hand, the decrease in mantle potential temperature $\left(\mathrm{T}_{\mathrm{P}}\right)$ when plume-influenced mantle is

485 replaced with ambient upper mantle reduces the degree of melting and thus holds the

486 LREE/MREE ratio relatively constant (Tegner et al., 1998; Hanghoj et al., 2003). Smaller

487 contributions from a mantle plume to a melting column will result in a decreasing $\mathrm{T}_{\mathrm{P}}$, which will

488 also impact the MREE/HREE ratios of generated magmas. A lower mantle $\mathrm{T}_{\mathrm{P}}$ will initiate

489 melting at shallower depths, thereby increasing the fraction of melt generated within the spinel

490 lherzolite field, resulting in less fractionated MREE/HREE ratios. Further complexity arises

491 when the role of pyroxenite in an upwelling plume is considered (Sobolev et al., 2005; Sobolev

492 et al., 2007; Herzberg, 2011). The REE characteristics of these dikes are likely the result of

493 multiple overlapping processes, and to resolve these we must establish the temporal

494 heterogeneity in the contribution from the Afar plume to magmatism.

$496 \quad 5.3$ Temporal evolution of geochemical reservoirs along the western Afar margin

497 5.3.1. Geochemical reservoirs contributing to magmatism

498 Previous studies in the region have placed constraints as to the potential geochemical

499 reservoirs contributing to magmatism in the Ethiopian magmatic province typically by 
500 examining temporally restricted portions of the province (e.g., flood basalts or Quaternary rift

501 activity: Pik et al., 1999; Rooney et al., 2012a). The suite of dikes that erupted along the western

502 Afar margin is spatially restricted but temporally diverse, representing a 25 Myr window on the

503 evolution of the magmatic reservoirs contributing to magmatism at a single location. The

504 influence of a mantle plume is observed throughout the temporal magmatic record in East Africa

505 (e.g., Rooney et al., 2012c). In modern magmas, the isotopic signature of a mantle plume is most

506 pronounced towards Djibouti (Schilling et al., 1992; Rooney et al., 2012a), consistent with

507 maximum $\mathrm{T}_{\mathrm{P}}$ values recorded in this area (Rooney et al., 2012c). Another asthenospheric

508 reservoir that displays characteristics that are broadly similar to the source of MORB is also

509 necessary to fully account for the magmatic heterogeneity observed in Afar and along the Gulf of

510 Aden (Schilling et al., 1992). The Pan-African lithosphere is a ubiquitous contributor to the

511 magmatic heterogeneity observed in the region (Hart et al., 1989; Deniel et al., 1994; Trua et al.,

512 1999; Furman et al., 2006). For the western Afar dikes, the contribution from Pan African

513 lithospheric end-member increases with declining $\mathrm{MgO}$, and can be interpreted as lithospheric

514 (likely crustal) assimilation by asthenospheric melts during fractional crystallization in the crust.

515 It is the interaction of these three reservoirs that account for the majority of geochemical

516 heterogeneities observed in regional magmas.

517 Mixing models which were developed to account for the isotopic characteristics of

518 Quaternary basalts from the Gulf of Aden and Main Ethiopian Rift have concluded that ternary

519 mixing is evident between the Pan-African lithosphere, a depleted component thought to

520 represent the upper mantle MORB source beneath the Gulf of Aden, and material derived from

521 the Afar Plume (Schilling et al., 1992; Rooney et al., 2012a). These models further revealed

522 complex patterns of reservoir interaction requiring the hybridization of the upper mantle MORB- 
523 like reservoir by mixing with foundered lithospheric materials (Rooney et al., 2012a). Using the

524 same end-members and isotopic values, we have adopted the ternary mixing hypothesis of

525 Rooney et al., (2012a). To simplify the visualization of ternary mixing within the multi-isotope

526 space ( $\mathrm{Sr}-\mathrm{Nd}-\mathrm{Pb}-\mathrm{Hf})$ occupied by our samples, we have performed a principal components

527 analysis (Fig. 10). The majority of isotopic variance is accounted for within the plane of the first

528 two eigenvectors (97.1\%), and therefore the isotopic variation is best illustrated by a PC-1/PC-2

529 projection. PC-1 is dominated by heterogeneity in terms of the depleted upper mantle and Pan-

530 African lithosphere end-members. While some variance on the PC-1 plane may be the result of a

531 hybridized upper mantle (Rooney et al., 2012a), evidence of covariance of isotopic systems with

$532 \mathrm{MgO}$ highlights the role of AFC processes for the western Afar dikes. PC-2 is most affected by

533 contributions from the Afar plume end-member (Fig. 10).

5.3.2. Groups 1 and 2 dikes: flood basalt eruption and subsequent diking between 31 and $27 \mathrm{Ma}$

Our results indicate that the single isotopically characterized sample of HT-1 basalt

537 (Group 2; EKA-112B) contains a significant contribution from depleted mantle and Pan-African

538 lithosphere reservoirs with relatively small contribution from the Afar plume. This observation is

539 consistent with standard isotope plots showing. EKA-112B falls closer to the Pan-African

540 endmember in comparison to other regional HT-1 magmas. Group 1 dolerites, while having

541 similar trace element characteristics to LT basalts of the western plateau, differ in that they carry

542 little of the depleted mantle component that is ubiquitous in LT basalts elsewhere. Thus dolerite

543 EKA-120 appears to have been derived from an almost binary mixture of Afar plume and pan-

544 African lithosphere endmembers, and both Group 1 dolerites plot closer to the "C" reservoir than

545 any previously analyzed flood basalt (Fig. 5; 10). An important implication follows, that there is 
546 a decoupling between the isotopic and trace element characteristics of the Afar mantle plume.

547 Specifically, the isotopic characteristics of the radiogenic end-member of the Afar plume (e.g. 548 radiogenic $\mathrm{Pb}$ isotopes), previously attributed only to the HT-2 basalts (Pik et al, 1999) can also

549 be found in some LT basalts represented by our Group 1 dolerites.

551 5.3.2 Group 4 dikes: Shield volcanism between 25 and $12 \mathrm{Ma}$

Group $4 \mathrm{~b}$ dolerites, which are related to the $\sim 22-25 \mathrm{Ma}$ Guguftu shield volcano, show

553 evidence of mixing between the Afar plume and the pan African lithosphere components (Fig.

554 10). We suggest that plume-derived melts assimilated Pan-African crustal materials during

555 magma differentiation. However, identity of the plume component in the $\sim 25-22$ Ma shield

556 basalts is debated (Kieffer et al., 2004). Previous research notes that the Choke and Guguftu

557 basaltic shield volcanoes have more elevated $\mathrm{Pb}$-isotopic values compared to the underlying

558 Oligocene flood basalts (Kieffer et al., 2004). This isotopic heterogeneity is mirrored in the trace

559 element characteristics, where the 25-22 Ma basalts bear similarities to Quaternary basalts in the

560 Ethiopian rift and the northern Kenyan rift (Furman et al., 2004; Furman et al., 2006). The

561 radiogenic end-member in the shield basalts of the western Ethiopian plateau has been

562 interpreted to be a HIMU-like component within a complex upwelling (Kieffer et al., 2004),

563 though the $\mathrm{Pb}$ isotopic values of these shield volcanoes lie close to the " $\mathrm{C}$ " mantle reservoir (Fig.

564 5). Hf isotopic data in this study preclude a dominantly HIMU-like component in the western

565 Afar dikes, and instead favor derivation from a "C"-like reservoir (Fig. 7; 8) similar to that for

566 the Oligocene flood basalts (Marty et al., 1996; Furman et al., 2006).

567 From our data it is apparent that from $\sim 30$ to $22 \mathrm{Ma}$, the depleted mantle did not play a 568 significant role in magma generation (Fig. 5), and as a result, the $\mathrm{Pb}$ isotope signature in basalts 
569 throughout this period reflects mixing between an endmember composed almost entirely of the

570 Afar plume and the Pan African lithosphere. The modest degree of magmatism during this period

571 (isolated shield volcanoes and dikes) argues against an increased plume flux in comparison to the

572 initial flood basalt eruptions. However, potentially fertile and warm plume material located in the

573 upper mantle that perhaps had not participated in melting during the initial flood basalt event or

574 were part of a complex upwelling (Kieffer et al., 2004; Bastow et al., 2008; Rooney et al., 2012c)

575 might be expected to melt preferentially as modest extension commenced along the Afar margin.

576 The 20-12 Ma interval represented by Group 4a dolerites in the Desse-Eloa transect

577 correlates with a period of reduced basaltic volcanism around Afar, and coincided with ongoing

578 lithospheric extension throughout the region. In addition to rifting along the western Afar

579 margin, rifting at this time occurred in southern Ethiopia (Bonini et al., 2001), whilst sea-floor

580 spreading was initiated in the Gulf of Aden and Red Sea (Bosworth et al., 2005, and references

581 therein). The Group 4a dikes were therefore injected during an important dynamic phase in

582 regional development of extension of the Afar margins. Group 4a dolerites plot close to the

583 binary mixing region between Pan African lithosphere and the depleted mantle end-members

584 (Fig. 5; 10), implying a lesser contribution from the Afar plume, in sharp contrast to the 30-22

585 Ma time period (Fig. 5).

586

\subsubsection{Group 3 dikes: Evolution of rifting from 10 Ma to Recent}

588 The period commencing at $\sim 10$ Ma marked the initiation of rifting in the northern

589 Ethiopian rift and the eventual connection of the rift basins in Afar and central Ethiopia (Kazmin

590 et al., 1981; Bonini et al., 2005; Wolfenden et al., 2005; Corti, 2009). Trace element and isotopic

591 characteristics of Group 3 dolerites indicate a more significant contribution from the depleted 
592 mantle in their petrogenesis in comparison to other groups (Fig. $2 ; 5 ; 7 ; 8 ; 10)$. While this

593 component is of the same magnitude as in Group 4a dolerites (e.g., EKA-106), the two are

594 distinguished by smaller lithospheric contributions in the Group 3 dolerites (e.g., Fig 10). Our

595 data confirm previous studies on Afar margin lavas which show that, with decreasing age, the

596 isotopic properties of the basalts express a more-depleted composition. This is interpreted simply

597 as an increased contribution from the depleted upper mantle and a lessening of crustal

598 assimilation (Hart et al., 1989). A similar pattern is observed in Djibouti where early volcanic

599 products (>10 Ma) exhibit substantial lithospheric contributions, but which become insignificant

600 as rifting and lithospheric thinning progress, replaced by an increasing fraction of melt derived

601 from depleted upper mantle and the Afar plume (Deniel et al., 1994).

602

6035.4 Rift evolution at the western Afar margin and comparisons to East Greenland

Tectonic thinning alone is an inadequate mechanism to explain the evolution of the East

606 African Rift System (Berckhemer et al., 1975; Mohr, 1983b). The concept that magmatic

607 intrusions can significantly weaken the continental lithosphere, leading ultimately to its rupture,

608 is now widely accepted in hypotheses of rift evolution (Klausen and Larsen, 2002; Buck, 2004;

609 Buck, 2006; Bialas et al., 2010). The best exposed example of magma-rich breakup is the East

610 Greenland continental margin, where glacier-cleared exposure reveals a regional pattern of

611 diking, faulting and warping in a breakup zone initiated over a mantle plume (Myers, 1980;

612 Klausen and Larsen, 2002; Hanghoj et al., 2003). The dikes along the western Afar margin share

613 many of the same characteristics of the East Greenland dike swarm. The East Greenland swarm

614 is broadly divided into an early stage of mafic diking that compositionally correlates with the 
615 regional flood basalt sequences, and a later less MgO-rich period of diking that does not correlate

616 with the erupted flood basalts (Hanghoj et al., 2003). Similar to these observations, early dikes

617 from western Afar are compositionally related to the regional flood basalt sequences and are

618 relatively mafic. Later dikes from western Afar are similar to those from east Greenland that are

619 typically less mafic and have no extrusive equivalent within the flood basalt sequence.

620 Statistical treatment of more than 1400 dikes (Klausen and Larsen, 2002) documents a

621 progressive shift in orientation from predominantly subvertical inland to predominantly landward

622 dipping (as low as $40^{\circ}$ ) offshore. This expresses the progressive seaward rotation of crustal units

623 during the evolution of the margin (Morton and Black, 1975). Exposed dikes in the Afar margins

624 are an order less numerous than in East Greenland. Nevertheless they share the same plateau-

625 ward/inland dip, although an eastward decrease in the riftward dip angle of increasingly more

626 abundant dikes is not observed along the Dessie-Eloa transect (cf. Wolfenden et al., 2005),

627 perhaps a result of the cover of younger lavas in the easternmost part of the transect.

628 Our interpretation of the tectonic and magmatic evolution of the western Afar margin

629 follows the three-stage rifting process proposed by Buck (2006): an initial stage of voluminous

630 magmatic intrusion, an intermediate stage dominated by tectonic stretching, and a final stage

631 where focused magmatic intrusion dominates strain accommodation:

632

633 5.4.1 Stage 1: Voluminous magmatic intrusion

634 The initial stages of rifting coincide with the emplacement of melt at various levels

635 within the lithosphere. Depending on the supply of magma, not all dikes may attain the surface.

636 However, even small volumes of magma at the early stage of rift development may have a

637 significant impact in subsequent rift evolution (Bialas et al., 2010). Within our study region the 
638 Group 2 dikes, related to the initial plume-head impact, strike rift-parallel precisely as predicted

639 by models of initial magma-assisted rifting (Buck, 2006). The Ethiopian Oligocene flood-basalt

640 pile attests to the enormous volumes of magma available to assist initiation of Afar margin

641 rifting (Fig. 11A). The African lithosphere is considered to have a typical thickness of $120 \mathrm{~km}$

642 (Dugda et al., 2007), which requires some preliminary thinning process to have occurred before

643 rifting could commence (Bialas et al., 2010). Existing studies (e.g., Ayalew \& Gibson 2009),

644 provide evidence that the necessary lithospheric thinning under Afar occurred during the impact

645 of the Afar plume, perhaps from transformation and erosion at the base of the lithosphere,

646 although the extent and magnitude of this thinning remain uncertain.

647

$648 \quad$ 5.4.2 Stage 2: Tectonic stretching

649 The second stage of rifting was characterized by a shift towards a greater degree of

650 lithospheric stretching and faulting, proceeding rapidly in regions where previous magmatic

651 injection had been voluminous (Bialas et al., 2010). Tectonic extension dominated this stage,

652 while magmatism was greatly reduced. Whereas the initial, Oligocene flood-basalt event is well-

653 represented in both Ethiopia and Yemen, the subsequent rifting of the African-Arabian continent

654 involving the drift of Arabia away from the Afar plume reduced volcanic activity on the eastern

655 flank of the Red Sea rift (Ukstins et al., 2002). In contrast, the western Afar margin preserves

656 evidence of a wide temporal range of magmatic products, and offers insight into the relationship

657 between magmatism and extension along an evolving rift margin. The diking associated with

658 continued extension along the western Afar margin can be broadly divided on the basis of

659 geochemistry into two events, represented by Group 4b dikes (Fig. 11B; 25-22 Ma), and Group

660 4a dikes (Fig. 11C; 20-12 Ma). They confirm that stretching and faulting of the western Afar 
661 crust was accompanied by local volcanism and magmatically induced subsidence that

662 progressively moved riftwards with time (Fig 11C: Wolfenden et al., 2005).

664 dikes; 25-22 Ma) was located at the rift border fault on the Desse-Eloa transect and fed

665 construction of the Guguftu shield volcano on the plateau rim (Fig 11B: Kieffer et al., 2004;

666 Wolfenden et al., 2005). Further riftward migration of strain was accompanied by local diking

667 and volcanism (20-12 Ma), significantly closer to Afar (Fig 11C: Justin-Visentin and Zanettin,

668 1974; Morton et al., 1979). Nevertheless, a simple model of the younging of dikes towards the

669 rift zone is complicated in the western Afar margin by overprinting. Contemporaneous lavas

670 along the rift margin have a magmatic signature in common with the Desse-Eloa dolerites,

671 revealing the assimilation of continental lithosphere by asthenosphere-derived basaltic magmas

672 (e.g., Fig. 5, 10), and the generation of a significant volume of silicic magmas (erupted as

673 ignimbrites) derived by fractional crystallization of the same basalts (Ayalew and Gibson, 2009).

674 The increase in silicic volcanism during the 20-12 Ma period was related to the ongoing

675 lithospheric extension. Fractional crystallization of basaltic magma rather than anatexis of

676 continental crust was the major source for the silicic magmas of the Afar and rift valley margins

677 (Ayalew et al., 2002; Peccerillo et al., 2003; Peccerillo et al., 2007; Ayalew and Gibson, 2009;

678 Rooney et al., 2012b). A lessened magma supply rate, resulting in magmatic intrusion at greater

679 depths and slower cooling (Behn et al., 2006), fostered crystal fractionation processes together

680 with lithospheric assimilation. Additionally, rift faulting and fissuring within the continental

681 crust facilitated shallow-level magmatic intrusion and differentiation (Antonellini and Cambray,

682 1992), together with stagnation of laterally migrating magma in the footwall of the faults (Bonini

683 et al., 2001). Volcanic periodicity may reflect the complex relationship between magma 
684 chamber size, supply rate, and crystallinity (Jellinek and DePaolo, 2003). In rift margin

685 environments, variations in the modeled strain field of a flexing plate (whereby melt at the base

686 of the crust travels to the surface through fractures: Ellis and King, 1991) might also account for

687 some degree of the periodicity of volcanism, allowing longer magma storage in the continental

688 crust under the rift flanks. Accumulation of magma in the footwall of a rift border-fault can

689 produce a feedback whereby rheology changes reduce the strength of the lithosphere, in turn

690 resulting in a period of further faulting and intrusion (Bonini et al., 2001).

691

692 5.4.3 Stage 3: strain accommodation by magmatic intrusion

693 In the third and final stage of rift development, extension became focused at the rift axis

694 (Mohr, 1978; Bilham et al., 1999; Ebinger and Casey, 2001; Casey et al., 2006; Rooney et al.,

695 2011), manifested as intensive diking through severely thinned lithosphere (Ebinger and Casey,

696 2001; Buck, 2004; Keranen et al., 2004; Wolfenden et al., 2005; Buck, 2006; Maguire et al.,

697 2006). At this stage ( $<10 \mathrm{Ma})$, the western Afar margin was the site of local volcanism on a scale

698 of segmentation similar to that of stage 2 but migrated closer to the rift floor (Fig. 11D). Group 3

699 dikes samples have a significantly weaker lithospheric signature in comparison to Group 4a

700 dikes, consistent with asthenospheric reservoirs becoming progressively more important in

701 controlling the isotopic compositions of basaltic magmas as the rift margin evolved and

702 magmatic injection became more focused (Hart et al., 1989; Deniel et al., 1994).

703 Our results show a temporal variation in the contribution of the Afar plume and depleted

704 mantle to western Afar magmas, defined by an initial strong plume signature (Groups 1 and $4 \mathrm{~b}$ )

705 that becomes less pronounced in the later groups (Groups 3 and 4a; Fig. 10). Modest lithospheric

706 thinning during the later development of the continental rift margin, from $20 \mathrm{Ma}$ onward, 
707 facilitated decompressional melting of the depleted upper mantle (Figs. 5, 10). Initially the 708 western Afar margin at latitude $11^{\circ} \mathrm{N}$ was situated close to the center of the Afar plume during

709 the flood-basalt event and initial rifting (Beccaluva et al., 2009), but continued lithospheric

710 extension and the formation of new rift lithosphere then shifted the margin away from the plume

711 center which is now located under Lake Abhe in central Afar (Schilling et al., 1992). The

712 significant spatial heterogeneity among the late Cenozoic asthenospheric reservoirs contributing

713 to magmatism beneath Djibouti and western Afar is surprising, considering the short distance

$714(170 \mathrm{~km})$ between the two regions (Schilling et al., 1992). It may reflect a progressively greater

715 dispersion and preferential channeling of the Afar plume beneath the extending lithosphere

716 (Sleep, 2008), which is consistent with geochemical, bathymetric, gravity, magnetic, and

717 magneto-telluric data from the Gulf of Aden and Main Ethiopian Rift (Schilling et al., 1992;

718 Leroy et al., 2010; Rooney et al., 2012a).

719

720 6. Conclusions

721 The western margin of Afar was formed by lithospheric and crustal extension accompanied by

722 major diking and volcanism during the Oligocene to Quaternary evolution of the Afar rift basin.

723 Magmatic activity, though varying in intensity throughout this evolution, spanned the entire

724 history of the progressive continental rifting that formed the margin. Dike and lava samples from

725 the margin now provide a window into the mantle sources and reservoirs involved, and the

726 interaction and changing contributions from Afar plume, African lithosphere and depleted upper

727 mantle melts. New ${ }^{40} \mathrm{Ar} /{ }^{39} \mathrm{Ar}$-geochronology places further constraints on the magmatic events of

728 the margin, in which five broad episodes are revealed: 
729 1) The earliest dikes were contemporaneous with the $31-29$ Ma flood-basalt province that covered much of Ethiopia and western Yemen (Fig. 11a). The geochemistry of these dikes resembles that of the HT-1 flood basalt flows which they intruded, though the dikes extend to significantly more mafic compositions (up to $12 \% \mathrm{MgO}$ ). The impact of the Afar mantle plume head at $\sim 31 \mathrm{Ma}$ initiated thinning of the overlying lithosphere and promoted melting of the depleted mantle and African lithosphere, generating magmas that were a broad mix of all three geochemical reservoirs. dikes resembles that of the LT flood basalts, but isotopes reveal that the dikes magmas contained a significantly elevated plume component compared with flood basalt magmas erupted elsewhere on the western Ethiopian plateau.

2) From $\sim 30$ to $27 \mathrm{Ma}$, a second, less intense stage of diking coincided with a broad lull in volcanic activity across the margin (Fig. 11b). The trace-element geochemistry of these

3) From 25 to $22 \mathrm{Ma}$, formation of the Guguftu and Choke basaltic shields on the adjacent plateau coincided with a significant increase in margin diking (Fig. 11b). The basalts and dolerites share a similar geochemsistry. The Afar plume contributed significantly to these magmas, although assimilation of African lithosphere (likely crust) supplied the heterogeneity evident in the radiogenic isotopic values. The minimal presence of a depleted mantle component from $\sim 30$ to 22 Ma could be the result of limited mantle upwelling due to the inferred small degree of lithsopheric thinning during this time period.

4) From 20 to $12 \mathrm{Ma}$, the evolving rift margin drifted away from the site of the plume. Decompressional melting of the depleted mantle became an important melt generation mechanism for the dike magmas as extension proceeded, though contributions from the 
Afar plume persisted. Widespread silicic magmatism across the margins of Afar was coincident with a spread of mafic diking (Fig. 11c) carrying a significant lithospheric component.

5) The final stage of margin diking commenced at $\sim 10 \mathrm{Ma}$. It coincided with the development of a spread of oblique faulting across the margin, and a narrow rift-parallel graben adjacent to the plateau (Fig. 11d). Magmatic intrusion was focused at two locations: at the easternmost sector of the margin, and in the marginal graben. Dikes and magmas of this period, like the preceding period, had a significant contribution from the depleted, asthenospheric mantle. However, further maturation of the margin led to a more established magmatic plumbing system at the riftward edge of the margin leading to a diminished lithospheric contribution to magmas of this period.

\section{Acknowledgements}

The authors wish to thank Matthew Parsons, Chelsea Mack, Tim Matthews, Thomas Hudgins and Christian Briggs who assisted with sample preparation and analysis. Emmanuel Ponzevera performed the Neptune ICMPS measurements for $\mathrm{Pb}, \mathrm{Nd}$ and $\mathrm{Hf}$ isotopes. PM expresses gratitude to Professor Pierre Gouin, S.J., for vital support at base during the original field mapping and sampling of the western Afar margin dikes in 1969. TR thanks Clifton Rooney for assistance with figures. Discussions with Dan McKenzie and Eric Grunsky assisted in our data interpretation. We thank Wendy Nelson, Cindy Ebinger, Ian Bastow, and Derek Keir for comments that improved the manuscript. Ingrid Uskins-Peate, Karen Hanghøj, and an anonymous reviewer provided detailed and helpful reviews which enhanced the manuscript. Finally we thank Steve Shirey for careful editorial handling.

\section{FIGURE 1.}

Spatial distribution of dike samples throughout the region. The approximate alignment of the Desse-Eloa highway is shown for reference. Topography is a digital elevation model based on the NASA/JPL SRTM dataset. The structural basins outlined by Wolfenden et al., (2005) are 
780 outlined: stage 1 basin - dark grey filling, stage 2 basin - dotted fill, stage 3 basin - vertical 781 lines. Additional samples presented in Hart et al., (1989) are also shown. Towns referred to in the

782 text are denoted by stars. A) Inset region is topography of the Afar triple junction region showing 783 the broad structural features including the Main Ethiopian Rift, Red Sea, and Gulf of Aden; B) 784 Inset of the regional tectonic framework focusing on structural basins (labelled 1-3; Wolfenden 785 et al., 2005). Pliocene-Quaternary basaltic magmatism within the Ethiopian rift is also shown for 786 reference (Rooney et al., 2011); C) Dikes less from 20 to $6 \mathrm{Ma}$ (Groups 3, 4a); D) Dikes from 78731 to $24 \mathrm{Ma}($ Groups $1,2,4 \mathrm{~b})$.

\section{FIGURE 2}

789 Chondrite normalized (Boynton, 1984) rare earth element pattern outlining the variation among 790 the different dike groupings. The low trace element abundance of group 1 dikes is particularly 791 apparent. Also of note are the low and elevated values of HREE in groups 2 and 3 respectively.

\section{FIGURE 3}

794 Primitive mantle normalized (Sun and McDonough, 1989) trace element diagrams of dike groups $7951-4$. Contemporaneous basalts are shown as shaded backgrounds for each group.

a. Low-Ti (LT) basalts from our study area (group 1) in comparison to other LT basalts from the western Ethiopian plateau (Pik et al., 1999; Kieffer et al., 2004; Beccaluva et al., 2009). Group 1 samples plot within the range of other western plateau samples and exhibit a similar trace element pattern. western Ethiopian plateau (Pik et al., 1999; Beccaluva et al., 2009). Patterns between both series broadly correlate though group 2 samples extend to depleted values of the 
more compatible elements, and higher values of $\mathrm{Nb}$-Ta in comparison to other $\mathrm{HT}-1$ basalts.

c. Group 3 basalts are shown in comparison to Quaternary volcanic rocks from the Main Ethiopian Rift (Rooney et al., 2005; Furman et al., 2006; Rooney et al., 2007; Rooney, 2010). Our group 3 differs markedly from the Quaternary rift-floor volcanic in the MER by having much more enriched values of HREE and an overall flatter trace element profile.

d. Group 4a samples are plotted against contemporaneous Getra Kele rift margin basalts of southern Ethiopia (George and Rogers, 2002). While group 4a plots with the Getra Kele basalts in terms of the more incompatible elements, there is a distinct heterogeneity between the two in terms of the more compatible elements - group 4a samples are significantly more enriched.

e. Group 4b samples which likely are related to the Guguftu shield volcano are plotted against the two volcanic shields which have developed at this time (Guguftu and Choke; Kieffer et al., 2004). Group 4b overlaps with Guguftu basalts in terms of the more

\section{FIGURE 4}

823 a. $\mathrm{MgO}-\mathrm{X}$ diagrams illustrating the variance between different Oligocene basalts in Ethiopia (Pik et al., 1999; Kieffer et al., 2004; Beccaluva et al., 2009) and Yemen (Baker et al., 1996b).

b. MgO-X diagrams illustrating the variance between our group 3 and the $10 \mathrm{Ma}-\mathrm{Recent}$ 
activity in MER of Ethiopia (Rooney et al., 2005; Furman et al., 2006; Rooney et al., 2007; Rooney, 2010), Pliocene-Quaternary Djibouti, Quaternary Asal Rift, and 4-9 Ma Dahla series (Deniel et al., 1994).

c. $\mathrm{MgO}-\mathrm{X}$ diagrams illustrating the variance between the rift margin and shield building phase of the Ethiopian plateau and group 4 of this study. We show that group 4a (19-12 $\mathrm{Ma}$ ) is distinct from the contemporaneous Getra Kele formation of southern Ethiopia in most element plots (Stewart and Rogers, 1996; George and Rogers, 2002). The distinct major element trends (e.g. $\mathrm{CaO} / \mathrm{Al}_{2} \mathrm{O}_{3}$ ) reflect the unusually deep clinopyroxenedominated fractionation of the Getra Kele basalts (George and Rogers, 2002). Group 4b displays a similar range in trace elements when compared to the 22-25 Ma Choke and Guguftu shield volcanoes (Kieffer et al., 2004). Groups 4a can be distinguished easily from group 4b, and displays elevated $\mathrm{Zr}$.

\section{FIGURE 5.}

$\mathrm{Pb}$ isotope variation plot showing our samples and other similar units in the region. A) ${ }^{208} \mathrm{~Pb} /{ }^{204} \mathrm{~Pb}$ versus ${ }^{206} \mathrm{~Pb} /{ }^{204} \mathrm{~Pb}$. B) ${ }^{207} \mathrm{~Pb} /{ }^{204} \mathrm{~Pb}$ versus ${ }^{206} \mathrm{~Pb} /{ }^{204} \mathrm{~Pb}$. Group 3 dikes are shown along with contemporaneous samples from western Afar reported by Hart et al., (1989). Data sources are: Getra Kele (Stewart and Rogers, 1996; George and Rogers, 2002); Choke/Guguftu (Kieffer et al., 2004); Djibouti includes Dahla, Asal rift and Pliocene-Quaternary basalts (Schilling et al., 1992; Deniel et al., 1994); MER - Main Ethiopian Rift (Furman et al., 2006; Rooney et al., 2012a); Gulf of Aden (Schilling et al., 1992); Yemen (Oligocene) (Baker et al., 1996b); western plateau HT1/HT2/LT (Pik et al., 1999; Kieffer et al., 2004). All data (our newly presented and existing data) older than $\sim 10 \mathrm{Ma}$ is age corrected. " $\mathrm{C}$ " is the mantle reservoir outlined by Hanan \& Graham (1989) and the assumed composition of the Afar Plume (Furman et al., 2006). Afar Plume, DM (depleted mantle) and PA (Pan African lithosphere) are endmembers modelled to 
851 contribute to magmatism in the region (Schilling et al., 1992; Rooney et al., 2012a). The northern

852 hemisphere reference line (NHRL: Hart, 1984) is also drawn.

\section{FIGURE 6}

$854{ }^{143} \mathrm{Nd} /{ }^{144} \mathrm{Nd}$ vs ${ }^{87} \mathrm{Sr} /{ }^{86} \mathrm{Sr}$ variation for samples within this study and other similar units in the 855 region. Endmembers and other regional datasets are those outlined in the caption of figure 5. 856 Note that all isotopes are age corrected except those less than $\sim 10 \mathrm{Ma}$. Group 1 overlaps the 857 values for Yemen, plotting at more radiogenic $\mathrm{Sr}$ and unradiogenic $\mathrm{Nd}$ in comparison to most 858 regional LT basalts, and consistent with an assimilation model. The single Group 2 dike plots 859 near to the Yemen field. It is apparent that our group $4 \mathrm{~b}$ data broadly overlap Choke/Guguftu at 860 the less radiogenic values of ${ }^{87} \mathrm{Sr} /{ }^{86} \mathrm{Sr}$ but fall at a slightly more radiogenic value for ${ }^{143} \mathrm{Nd} /{ }^{144} \mathrm{Nd}$.

861 Group 4 b extends towards extremely radiogenic ${ }^{87} \mathrm{Sr} /{ }^{86} \mathrm{Sr}$, values typical of lithospheric 862 contributions. Group 4a samples plot in a similar array but are displaced to lower values of $863{ }^{143} \mathrm{Nd} /{ }^{144} \mathrm{Nd}$.

\section{$864 \quad$ FIGURE 7}

865 Variation of samples from this study shown with a field outlining the only other data suites in the 866 region that includes $\mathrm{Hf}$ isotopes. The undifferentiated Oligocene-Miocene western plateau 867 basalts and Quaternary western plateau basalts presented by Meshesha et al., $(2007 ; 2010)$ are 868 shown here for reference. We also include Quaternary data from the Gulf of Aden and Main 869 Ethiopian Rift (Rooney et al., 2012a). Trends shown in this plot broadly reflects other isotopes 870 systems - groups 1 and 2 lie above the mantle array. In contrast group $4 \mathrm{~b}$ samples plot at or 871 below the mantle array with increasing contributions from the Pan African endmember. This 872 pattern is mirrored by the Miocene-Oligocene and Quaternary samples from the western plateau 873 which extend to lower $\varepsilon_{\mathrm{Hf}}$ at the more differentiated end of the mixing array. While the precise 874 value of $\varepsilon_{\mathrm{Hf}}$ for the PA endmember remains unclear, it is lower than the mantle array. Group 3 
875 samples are more radiogenic than the " $\mathrm{C}$ " mantle reservoir, consistent with an increased role for 876 the depleted mantle component in their genesis.

878 FIGURE 8

$879 \varepsilon_{\mathrm{Hf}}$ shown against ${ }^{206} \mathrm{~Pb} /{ }^{204} \mathrm{~Pb}$ isotopes for samples from this study and other regional data suites

880 (see Figure 7 for data sources). This isotopic projection rules out a significant contribution from 881 a HIMU-like reservoir in the petrogenesis of any of our samples. Furthermore, data from the 882 undifferentiated Miocene-Oligocene western plateau rocks (which appear to extend towards 883 HIMU in an $\varepsilon_{\mathrm{Hf}^{-}} \varepsilon_{\mathrm{Nd}}$ projection) are displaced towards unradiogenic $\mathrm{Pb}$ isotopes.

FIGURE 9.

A) Score plot from our principal component analysis (PCA) of the REEs in our dike samples. See Table 5 for the details of PC1, 2 and 3. Dike groups are particularly apparent in this projection. See the main text and Table 5 for more details of the PCA analysis and description of the results.

B) REE ratio plot after Hanghøj et al., (2003). Samples approximately $>5 \% \mathrm{MgO}$ are shown here and values have been normalized to $\mathrm{C} 1$ chondrite. This projection illustrates the relative enrichment of LREE to MREE (La/Sm) and MREE to HREE (Dy/Yb).

893 FIGURE 10

894 Score plot from our PCA of the isotopic values for our dike groups 1-4. This principal 895 component analysis included $\varepsilon_{\mathrm{Hf}}, \varepsilon_{\mathrm{Nd}}$, and $\mathrm{Sr}$ in addition to the three $\mathrm{Pb}$ isotopes. Endmembers 896 are: "C" - Afar plume, DM - depleted mantle, PA - Pan African lithosphere. The endmember 
897 values are listed in Table 6. PC-1 records the relative contributions from the DM and PA

898 reservoirs while PC-2 reflects the contributions from the radiogenic "C" endmember interpreted

899 as the Afar Plume. The general restriction of data to within the plane of these two eigenvectors is

900 consistent with a ternary mixing model. The most radiogenic endmember of group $4 \mathrm{~b}$ may

901 extend to outside of this mixing array, though heterogeneity in the plume endmember is likely.

902 Samples from other studies (e.g. Hart et al., 1989) could not be plotted with this method as PCA

903 requires each sample to have the same number of data values - no Hf data is available for most

904 older datasets.

905 FIGURE 11

906 Cartoon outlining a potential model for the evolution of the western Afar margin. These cartoons

907 do not show contemporaneous activity within the rift (e.g., Rooney et al., 2011). See the text for 908 a full narrative.

909

910 TABLE 1

911 Summary of the existing stratigraphic groups defined by Wolfenden et al., (2005).

912 TABLE 2

913 Summary of dike and fault trends across the Afar margin between Desse and Eloa, presented in 914 detail elsewhere (Mohr, 1971).

915 TABLE 3

$916{ }^{40} \mathrm{Ar} /{ }^{39} \mathrm{Ar}$ geochronology results. Samples EKA-120 and EKA-119 were irradiated in package

917 number mc23, samples EKA-111 and EKA-112B were irradiated in package mc24 and samples

918 EAD-114, EKA-140A and EKA-153 were irradiated in package mc25. Packages mc23 and mc24 
919 were each irradiated for 15 hours (45 MWh) while package mc25 was irradiated for 2 hours (6

920 MWh). Standard hornblende MMhb-1 was used as the fluence monitor for packages mc23 and

921 mc24. Fish Canyon Tuff biotite split 3 (FCT-3) was used as the fluence monitor for package

922 mc25. The K-Ar age of 520.4 Ma was used for MMhb-1 in calculating J values (Samson and

923 Alexander, 1987) and an age of 27.99 Ma was used for FCT-3, which is a value previously

924 calibrated against MMhb-1 (Hall and Farrell, 1995). For each sample, a total gas age (TGA) was

925 calculated by adding up all of the gas fractions for a sample run. This age should most closely

926 mimic what would be expected from a conventional K-Ar age. In addition to the TGA values,

927 when possible, an error weighted plateau age (EWP) was also calculated. Plateau segments were

928 selected based on the following criteria: a) there are a minimum of 3 contiguous gas fractions

929 constituting at least $50 \%$ of the ${ }^{39}$ Ar released; and b) the error weighted mean of the segment

930 passes the null hypothesis that the calculated ages are all equal using a $\chi^{2}$ test at the $95 \%$

931 confidence level. When multiple plateau segments were available, the one with the minimum

932 error estimate was chosen. EWP ages include the effects of scatter about the error weighted mean

933 age. Given that the samples analyzed were whole-rock samples with fine-grained inclusions

934 having contrasting K-concentrations, the $\sim 80 \mathrm{~nm}$ recoil distance expected for ${ }^{39} \mathrm{Ar}$ might be

935 expected to contribute a significant amount to variations in ages within an age spectrum (Turner

936 and Cadogan, 1974). Specifically, if K-rich phases donate ${ }^{39}$ Ar into neighboring K-poor sites,

937 then if the different minerals degas at different temperatures, one would expect anomalously high

938 ages in the K-rich minerals and anomalously low ages in the K-poor ones. In order to account for

939 this, while still eliminating low temperature gas fractions with apparent Ar loss due to alteration

940 and/or diffusion, Turner et al., (1978) used the concept of a "reduced plateau" age which is

941 calculated by totaling the gas over the fractions that would have exhibited plateaus without ${ }^{39} \mathrm{Ar}$ 
942 recoil artifacts. In order to avoid confusion with the normal terminology of error weighted

943 plateaus, we refer to these ages as reduced integrated ages (RIA), as they are calculated by

944 integrating the gas release over a portion of the age spectrum. A combined isochron age (CIA)

945 was calculated by combining the gas fractions for all of a sample"s replicate analyses. Scatter

946 about the best fit line was included in the CIA error estimate. Details of the isochron fits as well

947 as the fractions used in the EWP and RIA ages are given in the supplementary material. In the

948 case of TGA, EWP and RIA ages, an error weighted average of the ages was calculated to

949 provide an overall sample age estimate. The TGA, EWP, RIA and CIA model age errors all

950 include the uncertainty in J. One of the 4 model ages was chosen as a "preferred" age and the

951 reasons for the choice of preferred age are outlined below. Laser fusion system blanks were

952 monitored regularly (typically every $5^{\text {th }}$ sample gas fraction) and typical measured blanks at

953 masses $36,37,38,39$, and 40 were about $4 \times 10^{-14}, 4 \times 10^{-14}, 4 \times 10^{-15}, 4 \times 10^{-14}$, and $7 \times 10^{-12}$ ccSTP

954 respectively.

956 TABLE 4

957 Isotopic characteristics of dikes along the Desse-Eloa transect. All $\mathrm{Hf}, \mathrm{Pb}$ and $\mathrm{Nd}$ isotope

958 measurements were made on a Thermo Neptune multi-collector inductively coupled plasma

959 mass spectrometer at Ifremer. Repeat measurements of the Hf isotope standard JMC 475 during

960 the course of the analyses yielded reproducibility of $46 \mathrm{ppm}(2 \sigma)$ on ${ }^{176} \mathrm{Hf} /{ }^{177} \mathrm{Hf}$ with a value of

961 0.282165. The $\mathrm{Pb}$ isotope data are reported relative to published values for NBS 981 in

962 Catanzaro et al., (1968). The samples were spiked with thallium to correct for mass fractionation.

963 Based on repeated runs of NBS 981 during the course of the analyses, the estimated external

964 precision for $\mathrm{Pb}$ analyses is $\pm 0.02 \%, 2 \sigma$ for ${ }^{206} \mathrm{~Pb} /{ }^{204} \mathrm{~Pb}$ and ${ }^{207} \mathrm{~Pb} /{ }^{204} \mathrm{~Pb}$ and $\pm 0.03 \%, 2 \sigma$ for 
$965{ }^{208} \mathrm{~Pb} /{ }^{204} \mathrm{~Pb}$. Repeat measurements of the Nd isotope standard JNdi-1 (Tanaka et al., 2000)

966 yielded ${ }^{143} \mathrm{Nd} /{ }^{144} \mathrm{Nd}$ values of $0.512114 \pm 12(2 \sigma, \mathrm{n}=8)$. Sr isotope measurements were performed

967 on a multicollector Finnigan MAT26X mass spectrometer upgraded by Spectromat. Replicate

968 analyses of NBS 987 during the analysis period gave an average value of $0.71025 \pm 3(2 \sigma, n=9)$.

969 Analysis of BCR-2 gave Hf-Pb-Sr-Nd values of ${ }^{176} \mathrm{Hf} /{ }^{177} \mathrm{Hf}=0.282861 \pm 9,{ }^{206} \mathrm{~Pb} /{ }^{204} \mathrm{~Pb}=$

$970 \quad 18.7528 \pm 6,{ }^{207} \mathrm{~Pb} /{ }^{204} \mathrm{~Pb}=15.6203 \pm 6,{ }^{208} \mathrm{~Pb} /{ }^{204} \mathrm{~Pb}=38.7355 \pm 19,{ }^{87} \mathrm{Sr} /{ }^{86} \mathrm{Sr}=0.705007 \pm 7$,

$971{ }^{143} \mathrm{Nd} /{ }^{144} \mathrm{Nd}=0.512639 \pm 4$ respectively.

972 TABLE 5

973 Eigenvectors from our principal components analysis of the REE patterns in our groups 1 to 4.

974 For details of the analysis and interpretations refer to the text.

975 TABLE 6

976 Endmember compositions used in plotting and for principal components analysis. For Sr, $\mathrm{Nd}$,

977 and $\mathrm{Pb}$ the isotopic values for the depleted mantle and Pan African lithosphere endmembers are

978 identical to Schilling et al., (1992). The Afar plume composition is set as the "C" mantle

979 reservoir of Hanan \& Graham, (1996). To facilitate incorporating the Hf isotopic system into our

980 interpretations, we make the assumption that the Afar plume and the regional upper mantle

981 depleted end-members lie along the $\varepsilon_{\mathrm{Nd}}-\varepsilon_{\mathrm{Hf}}$ mantle array $\left(\left[1.4^{*} \varepsilon_{\mathrm{Nd}}\right]+2.8\right)$, thereby deriving $\varepsilon_{\mathrm{Hf}}$

982 from existing $\varepsilon_{\mathrm{Nd}}$ values (Table 6). The poorly constrained $\varepsilon_{\mathrm{Hf}}$ values for the Pan African

983 lithosphere end-member likely lie below the mantle array, and to estimate them we performed a

984 best-fit for Group $4 \mathrm{~b}$ (this group extends to the least radiogenic values of $\varepsilon_{\mathrm{Nd}}$ and $\varepsilon_{\mathrm{Hf}}$ ). We then

985 derived $\varepsilon_{\mathrm{Hf}}$ from where this best-fit line intersects the plane defined by the modeled $\varepsilon_{\mathrm{Nd}}$ of the

986 Pan African lithosphere end-member. 
References

Abbate, E., Azzaroli, A., Zanettin, B. and Visentin, E.J., 1968. A geologic and petrographic mission of the "Consiglio Nazionale delle Ricerche" to Ethiopia 1967-1968 - Preliminary results. Bollettino Società Geologica Italiana, 87: 1-20.

Abbate, E. and Sagri, M., 1969. Datie considerazioni sul margine orientale dell'altopiano etiopico nell province del Tigrai e del Wollo. Bollettino Società Geologica Italiana, 88: 489-497.

Aitchison, J., 1986. The statistical analysis of compositional data. Chapman and Hall, London, New York.

Antonellini, M.A. and Cambray, F.W., 1992. Relations between sill intrusions and dedding-parallel extensional shear zones in the Midcontinent Rift System of the Lake-Superior region. Tectonophysics, 212(3-4): 331-349.

Ayalew, D., Barbey, P., Marty, B., Reisberg, L., Yirgu, G. and Pik, R., 2002. Source, genesis, and timing of giant ignimbrite deposits associated with Ethiopian continental flood basalts. Geochimica et Cosmochimica Acta, 66(8): 1429-1448.

Ayalew, D. and Gibson, S.A., 2009. Head-to-tail transition of the Afar mantle plume: Geochemical evidence from a Miocene bimodal basalt-rhyolite succession in the Ethiopian Large Igneous Province. Lithos, 112(3-4): 461-476.

Ayele, A., Stuart, G., Bastow, I. and Keir, D., 2007. The August 2002 earthquake sequence in north Afar: Insights into the neotectonics of the Danakil microplate. Journal of African Earth Sciences, 48(2-3): 70-79.

Bachmann, O. and Bergantz, G.W., 2008. Rhyolites and their source mushes across tectonic settings. Journal of Petrology, 49(12): 2277-2285.

Baker, J., Snee, L. and Menzies, M., 1996a. A brief Oligocene period of flood volcanism in Yemen: Implications for the duration and rate of continental flood volcanism at the Afro-Arabian triple junction. Earth and Planetary Science Letters, 138(1-4): 39-55.

Baker, J.A., Thirlwall, M.F. and Menzies, M.A., 1996b. Sr-Nd-Pb isotopic and trace element evidence for crustal contamination of plume-derived flood basalts: Oligocene flood volcanism in western Yemen. Geochimica Et Cosmochimica Acta, 60(14): 2559-2581.

Bastow, I.D. and Keir, D., 2011. The protracted development of the continent-ocean transition in Afar. Nature Geoscience, 4(4): 248-250.

Bastow, I.D., Nyblade, A.A., Stuart, G.W., Rooney, T.O. and Benoit, M.H., 2008. Rifting at the edge of the African low velocity anomaly. Geochemistry Geophysics Geosystems: Q12022, doi:10.1029/2008GC002107.

Bastow, I.D., Pilidou, S., Kendall, J.M. and Stuart, G.W., 2010. Melt-Induced seismic anisotropy and magma assisted rifting in Ethiopia: evidence from surface waves. Geochemistry Geophysics Geosystems: Q0AB05, doi:10.1029/2010GC003036 
1030

1031

1032

1033

1034

1035

1036

1037

1038

1039

1040

1041

1042

1043

1044

1045

1046

1047

1048

1049

1050

1051

1052

1053

1054

1055

1056

1057

1058

1059

1060

1061

1062

1063

1064

1065

1066

1067

1068

1069

1070

1071

1072

1073

1074
Beccaluva, L., Bianchini, G., Natali, C. and Siena, F., 2009. Continental flood basalts and mantle plumes: a case study of the Northern Ethiopian Plateau. Journal of Petrology, 50(7): 1377-1403.

Behn, M.D., Buck, W.R. and Sacks, I.S., 2006. Topographic controls on dike injection in volcanic rift zones. Earth and Planetary Science Letters, 246(3-4): 188-196.

Berckhemer, H., Baier, B., Bartelsen, H., Behle, A., Burkhardt, H., Gebrande, H., Makris, J., Menzel, H., Miller, H. and Vees, R., 1975. Deep seismic soundings in the Afar region and on the highland of Ethiopia. In: Pilger, A. and Roesler, A. (Eds), Afar between continental and oceanic rifting. Schweizerbart, Stuttgart, 89107.

Bialas, R.W., Buck, W.R. and Qin, R., 2010. How much magma is required to rift a continent? Earth and Planetary Science Letters, 292: 68-78.

Bilham, R., Bendick, R., Larson, K., Mohr, P., Braun, J., Tesfaye, S. and Asfaw, L., 1999. Secular and tidal strain across the main Ethiopian rift. Geophysical Research Letters, 26(18): 2789-2792.

Bonini, M., Corti, G., Innocenti, F., Manetti, P., Mazzarini, F., Abebe, T. and Pecskay, Z., 2005. Evolution of the Main Ethiopian Rift in the frame of Afar and Kenya rifts propagation. Tectonics, 24(1): TC1007, doi: 10.1029/2004TC00168.

Bonini, M., Sokoutis, D., Mulugeta, G., Boccaletti, M., Corti, G., Innocenti, F., Manetti, P. and Mazzarini, F., 2001. Dynamics of magma emplacement in centrifuge models of continental extension with implications for flank volcanism. Tectonics, 20(6): 1053-1065.

Bosworth, W., Huchon, P. and McClay, K., 2005. The Red Sea and Gulf of Aden basins. Journal of African Earth Sciences, 43(1-3): 334-378.

Boynton, W.V., 1984. Cosmochemistry of the rare earth elements: meteorite studies. In: Henderson, P. (Eds), Rare earth element geochemistry. Elsevier, New York.

Buck, W.R., 2004. Consequences of asthenospheric variability on continental rifting. In: Karner, G., Taylor, B., Driscoll, N.W. and Kohlstedt, D.L. (Eds), Rheology and deformation of the lithosphere at continental margins. Columbia University Press, New York, 1-30.

Buck, W.R., 2006. The role of magma in the development of the Afro-Arabian rift system. In: Yirgu, G., Ebinger, C. and Maguire, P. (Eds), The Afar Volcanic Province within the East African Rift System. Special Publication of the Geological Society, London, 43-54.

Casey, M., Ebinger, C., Keir, D., Gloaguen, R. and Mohamed, F., 2006. Strain accomodation in transitional rifts: Extension by magma intrusion and faulting in Ethiopian rift magmatic segments. In: Yirgu, G., Ebinger, C. and Maguire, P. (Eds), The Afar Volcanic Province within the East African Rift System. Geological Society, London, London, 143-164.

Catanzaro, E.J., Murphy, T.J., Shields, W.R. and Garner, E.L., 1968. Absolute isotopic abundance ratios of common equal-atom and radiogenic lead isotopic standards. Journal of Research of the National Bureau of Standards: Section a-Physics and Chemistry, 72A(3): 26.

Corti, G., 2009. Continental rift evolution: From rift initiation to incipient break-up in the Main Ethiopian Rift, East Africa. Earth-Science Reviews, 96(1-2): 1-53. 
1075

1076

1077

1078

1079

1080

1081

1082

1083

1084

1085

1086

1087

1088

1089

1090

1091

1092

1093

1094

1095

1096

1097

1098

1099

1100

1101

1102

1103

1104

1105

1106

1107

1108

1109

1110

1111

1112

1113

1114

1115

1116

1117

1118

1119

Daly, E., Keir, D., Ebinger, C.J., Stuart, G.W., Bastow, I.D. and Ayele, A., 2008. Crustal tomographic imaging of a transitional continental rift: the Ethiopian rift. Geophysical Journal International, 172(3): 1033-1048.

Deering, C.D., Cole, J.W. and Vogel, T.A., 2008. A rhyolite compositional continuum governed by lower crustal source conditions in the Taupo Volcanic Zone, New Zealand. Journal of Petrology, 49(12): 2245-2276.

Deniel, C., Vidal, P., Coulon, C. and Vellutini, P.J., 1994. Temporal evolution of mantle sources during continental rifting - the volcanism of Djibouti (Afar). Journal of Geophysical Research-Solid Earth, 99(B2): 2853-2869.

Dugda, M.T., Nyblade, A.A. and Julia, J., 2007. Thin lithosphere beneath the Ethiopian plateau revealed by a joint inversion of Rayleigh wave group velocities and receiver functions. Journal of Geophysical Research-Solid Earth, 112(B8): B08305, doi:10.1029/2006JB004918.

Ebinger, C., Ayele, A., Keir, D., Rowland, J., Yirgu, G., Wright, T., Belachew, M. and Hamling, I., 2010. Length and Timescales of Rift Faulting and Magma Intrusion: The Afar Rifting Cycle from 2005 to Present. Annual Review of Earth and Planetary Sciences, Vol 38, 38: 439-466.

Ebinger, C.J. and Casey, M., 2001. Continental breakup in magmatic provinces: An Ethiopian example. Geology, 29(6): 527-530.

Ebinger, C.J. and Sleep, N.H., 1998. Cenozoic magmatism throughout East Africa resulting from impact of a single plume. Nature, 395(6704): 788-791.

Ellis, M. and King, G., 1991. Structural control of flank volcanism in continental rifts. Science, 254(5033): 839-842.

Fialko, Y.A. and Rubin, A.M., 1999. Thermal and mechanical aspects of magma emplacement in giant dike swarms. J. Geophys. Res., 104(B10): 23033-23049.

Frey, H.M., Lange, R.A., Hall, C.M., Delgado-Granados, H. and Carmichael, I.S.E., 2007. A Pliocene ignimbrite flare-up along the Tepic-Zacoalco rift: Evidence for the initial stages of rifting between the Jalisco block (Mexico) and North America. Geological Society of America Bulletin, 119(1-2): 49-64.

Furman, T., Bryce, J.G., Karson, J. and lotti, A., 2004. East African Rift System (EARS) plume structure: Insights from quaternary mafic lavas of Turkana, Kenya. Journal of Petrology, 45(5): 1069-1088.

Furman, T., Bryce, J.G., Rooney, T., Hanan, B.B., Yirgu, G. and Ayalew, D., 2006. Heads and tails: 30 million years of the Afar plume. In: Yirgu, G., Ebinger, C. and Maguire, P. (Eds), The Afar Volcanic Province within the East African Rift System. Special Publication of the Geological Society, London, 95-120.

George, R.M. and Rogers, N.W., 2002. Plume dynamics beneath the African Plate inferred from the geochemistry of the Tertiary basalts of southern Ethiopia. Contributions to Mineralogy and Petrology, 144(3): 286-304.

Gortani, M. and Bianchi, A., 1937. Osservazioni geologiche e petrografiche nella regione di Harar (Africa Orientale Italiana). Bollettino Società Geologica Italiana, 56: 499-516.

Gortani, M. and Bianchi, A., 1973. Itinerari geologici nella Dancalia meridionale e sugli altipiani Hararini Missione Geologica dell'AGIP nella Dancalia Meridionale e sugli Altipiani Hararini (1936-1938). Accademia Nazionale Lincei, Roma, 240. 
Hall, C.M. and Farrell, J.W., 1995. Laser Ar-40/Ar-39 ages of tephra from Indian-Ocean deep-sea sediments - tie points for the astronomical and geomagnetic polarity Time Scales. Earth and Planetary Science Letters, 133(3-4): 327-338.

Hanan, B.B. and Graham, D.W., 1996. Lead and helium isotope evidence from oceanic basalts for a common deep source of mantle plumes. Science, 272(5264): 991 995.

Hanghoj, K., Storey, M. and Stecher, O., 2003. An isotope and trace element study of the East Greenland Tertiary dyke swarm: Constraints on temporal and spatial evolution during continental rifting. Journal of Petrology, 44(11): 2081-2112.

Hart, S.R., 1984. A large-scale isotope anomaly in the southern-hemisphere mantle. Nature, 309(5971): 753-757.

Hart, W.K., Woldegabriel, G., Walter, R.C. and Mertzman, S.A., 1989. Basaltic volcanism in Ethiopia - Constraints on continental rifting and mantle interactions. Journal of Geophysical Research-Solid Earth and Planets, 94(B6): 7731-7748.

Herzberg, C., 2011. Identification of Source Lithology in the Hawaiian and Canary Islands: Implications for Origins. Journal of Petrology, 52(1): 113-146.

Hofmann, C., Courtillot, V., Feraud, G., Rouchett, P., Yirgu, G., Ketefo, E. and Pik, R., 1997. Timing of the Ethiopian flood basalt event and implications for plume birth and global change. Nature, 389(6653): 838-841.

Huismans, R.S., Podladchikov, Y.Y. and Cloetingh, S., 2001. Transition from passive to active rifting: Relative importance of asthenospheric doming and passive extension of the lithosphere. Journal of Geophysical Research-Solid Earth, 106(B6): 11271-11291.

Hyodo, H. and York, D., 1993. The discovery and significance of a fossilized radiogenic argon wave (Argonami) in the Earth's crust. Geophysical Research Letters, 20(1): 61-64.

Jellinek, A.M. and DePaolo, D.J., 2003. A model for the origin of large silicic magma chambers: precursors of caldera-forming eruptions. Bulletin of Volcanology, 65(5): 363-381.

Jepsen, D.H. and Athearn, M.J., 1962. East-west geologic sections, Blue Nile river basin, Ethiopia. Dept. of Water Resources, Addis Ababa, Drawing No. 5.2 BN-3.

Justin-Visentin, E. and Zanettin, B., 1974. Dike swarms, volcanism and tectonics of the Western Afar margin along the Kombolcha-Eloa traverse (Ethiopia). Bulletin of Volcanology, 38: 187-205.

Kazmin, V., Berhe, S.M. and Wondm-Agennehu, B., 1981. Geological map of the Ethiopian Rift. The Ethiopian Government - Ministry of Mines, Energy and Water Resources, Addis Ababa.

Keir, D., Belachew, M., Ebinger, C.J., Kendall, J.M., Hammond, J.O.S., Stuart, G.W., Ayele, A. and Rowland, J.V., 2011a. Mapping the evolving strain field during continental breakup from crustal anisotropy in the Afar Depression. Nature Communications, 2.

Keir, D., Hamling, I.J., Ayele, A., Calais, E., Ebinger, C., Wright, T.J., Jacques, E., Mohamed, K., Hammond, J.O.S., Belachew, M., Baker, E., Rowland, J.V., Lewi, E. and Bennati, L., 2009. Evidence for focused magmatic accretion at segment centers from lateral dike injections captured beneath the Red Sea rift in Afar. Geology, 37(1): 59-62. 
1166

1167

1168

1169

1170

1171

1172

1173

1174

1175

1176

1177

1178

1179

1180

1181

1182

1183

1184

1185

1186

1187

1188

1189

1190

1191

1192

1193

1194

1195

1196

1197

1198

1199

1200

1201

1202

1203

1204

1205

1206

1207

1208

1209

1210

Keir, D., Pagli, C., Bastow, I.D. and Ayele, A., 2011b. The magma-assisted removal of Arabia in Afar: Evidence from dike injection in the Ethiopian rift captured using InSAR and seismicity. Tectonics, 30.

Keranen, K., Klemperer, S.L., Gloaguen, R., Asfaw, L., Ayele, A., Ebinger, C., Furman, T., Harder, S., Keller, G.R., Mackenzie, G.D., Maguire, P.K.H. and Stuart, G.W., 2004. Three-dimensional seismic imaging of a protoridge axis in the main Ethiopian Rift. Geology, 32(11): 949-952.

Kieffer, B., Arndt, N., Lapierre, H., Bastien, F., Bosch, D., Pecher, A., Yirgu, G., Ayalew, D., Weis, D., Jerram, D.A., Keller, F. and Meugniot, C., 2004. Flood and shield basalts from Ethiopia: Magmas from the African superswell. Journal of Petrology, 45(4): 793-834.

Klausen, M. and Larsen, H., 2002. East Greenland coast-parallel dike swarm and its role in continental breakup. In: Menzies, M., Klemper, S.L., Ebinger, C.J. and Baker, J. (Eds), Volcanic Rifted Margins. Geological Society of America, Boulder, Co, 133-158.

Leroy, S., d'Acremont, E., Tiberi, C., Basuyau, C., Autin, J., Lucazeau, F. and Sloan, H., 2010. Recent off-axis volcanism in the eastern Gulf of Aden: Implications for plume-ridge interaction. Earth and Planetary Science Letters, 293: 140-153.

Maguire, P., Keller, G.R., Klemper, S.L., Mackenzie, G., Keranen, K., Harder, S., O'Reilly, B., Thybo, H., Asfaw, L., Kahn, M. and Amha, M., 2006. Crustal structure of the Northern Main Ethiopian Rift from the EAGLE controlled source survey; a snapshot of incipient lithospheric break-up. In: Yirgu, G., Ebinger, C. and Maguire, P. (Eds), The Afar Volcanic Province within the East African Rift System. Special Publication of the Geological Society, London, 269-292.

Manhes, G., Minster, J.F. and Allegre, C.J., 1978. Comparative uranium-thorium-lead and rubidium-strontium study of Saint-Severin amphoterite - consequences for early Solar-System chronology. Earth and Planetary Science Letters, 39(1): 1424.

Marty, B., Pik, R. and Gezahegn, Y., 1996. Helium isotopic variations in Ethiopian plume lavas; nature of magmatic sources and limit on lower mantle contribution. Earth and Planetary Science Letters, 144(1-2): 223-237.

Megrue, G.H., Norton, E. and Strangway, D.W., 1972. Tectonic history of Ethiopian Rift as deduced by K-Ar ages and paleomagnetic measurements of basaltic dikes. Journal of Geophysical Research, 77(29): 5744-5754.

Meshesha, D., and Shinjo, R., 2007, Crustal contamination and diversity of magma sources in the northwestern Ethiopian volcanic province: Journal of Mineralogical and Petrological Sciences, v. 102, p. 272-290.

Meshesha, D., and Shinjo, R., 2010, Hafnium isotope variations in Bure volcanic rocks from the northwestern Ethiopian volcanic province: a new insight for mantle source diversity: Journal of Mineralogical and Petrological Sciences, v. 105, p. 101-111.

Mohr, P., 1971. Ethiopian Tertiary dike swarms, 339. Smithsonian Institution, Research in Space Science, SAO Special Report 339.

Mohr, P., 1978. Afar. Annual Review of Earth and Planetary Sciences, 6: 145-172.

Mohr, P., 1983a. Ethiopian flood basalt province. Nature, 303(5918): 577-584. 
1211

1212

1213

1214

1215

1216

1217

1218

1219

1220

1221

1222

1223

1224

1225

1226

1227

1228

1229

1230

1231

1232

1233

1234

1235

1236

1237

1238

1239

1240

1241

1242

1243

1244

1245

1246

1247

1248

1249

1250

1251

1252

1253

1254

1255

Mohr, P., 1983b. The Morton-Black hypothesis for the thinning of continental-crust revisited in western Afar. Tectonophysics, 94(1-4): 509-528.

Mohr, P., 1999. The Asmara dike swarm, Eritrean Plateau; physical parameters of an off-rift olivine dolerite injection zone. Acta Vulcanologica, 11(1): 177-181.

Mohr, P.A., 1962. The Ethiopian rift system. Bulletin of the Geophysical Observatory, $3(1): 33-62$.

Morton, W.H. and Black, R., 1975. Crustal attenuation in Afar. In: Pilger, A. and Rosler, A. (Eds), Afar Depression of Ethiopia. Schweizerbart, Stuttgart, 55-65.

Morton, W.H., Rex, D.C., Mitchell, J.G. and Mohr, P., 1979. Riftward younging of volcanic units in the Addis Ababa region, Ethiopian Rift valley. Nature, 280(5720): 284-288.

Myers, J.S., 1980. Structure of the coastal dyke swarm and associated plutonic intrusions of East Greenland. Earth and Planetary Science Letters, 46(3): 407418.

Peate, D.W., Barker, A.K., Riishuus, M.S. and Andreasen, R., 2008. Temporal variations in crustal assimilation of magma suites in the East Greenland flood basalt province: Tracking the evolution of magmatic plumbing systems. Lithos, 102(1-2): 179-197.

Peccerillo, A., Barberio, M.R., Yirgu, G., Ayalew, D., Barbieri, M. and Wu, T.W., 2003. Relationships between mafic and peralkaline silicic magmatism in continental rift settings: A petrological, geochemical and isotopic study of the Gedemsa volcano, central Ethiopian rift. Journal of Petrology, 44(11): 2003-2032.

Peccerillo, A., Donati, C., Santo, A.P., Orlando, A., Yirgu, G. and Ayalew, D., 2007. Petrogenesis of silicic peralkaline rocks in the Ethiopian rift: Geochemical evidence and volcanological implications. Journal of African Earth Sciences, 48(2-3): 161-173.

Pik, R., Deniel, C., Coulon, C., Yirgu, G., Hofmann, C. and Ayalew, D., 1998. The northwestern Ethiopian Plateau flood basalts. Classification and spatial distribution of magma types. Journal of Volcanology and Geothermal Research, 81(1-2): 91-111.

Pik, R., Deniel, C., Coulon, C., Yirgu, G. and Marty, B., 1999. Isotopic and trace element signatures of Ethiopian flood basalts; evidence for plume-lithosphere interactions. Geochimica et Cosmochimica Acta, 63(15): 2263-2279.

Renne, P.R., Deckart, K., Ernesto, M., Fe'raud, G. and Piccirillo, E.M., 1996. Age of the Ponta Grossa dike swarm (Brazil), and implications to Parana'flood volcanism. Earth and Planetary Science Letters, 144(1-2): 199-211.

Rooney, T., Furman, T., Bastow, I.D., Ayalew, D. and Gezahegn, Y., 2007. Lithospheric modification during crustal extension in the Main Ethiopian Rift. Journal of Geophysical Research, B, Solid Earth and Planets, 112: B10201, doi:10.1029/2006JB004916.

Rooney, T., Furman, T., Yirgu, G. and Ayalew, D., 2005. Structure of the Ethiopian lithosphere: Xenolith evidence in the Main Ethiopian Rift. Geochimica et Cosmochimica Acta, 69(15): 3889-3910.

Rooney, T.O., 2010. Geochemical evidence of lithospheric thinning in the southern Main Ethiopian Rift. Lithos, 117(1-4): 33-48. 
1256

1257

1258

1259

1260

1261

1262

1263

1264

1265

1266

1267

1268

1269

1270

1271

1272

1273

1274

1275

1276

1277

1278

1279

1280

1281

1282

1283

1284

1285

1286

1287

1288

1289

1290

1291

1292

1293

1294

1295

1296

1297

1298

1299

1300
Rooney, T.O., Bastow, I.D. and Keir, D., 2011. Insights into extensional processes during magma assisted rifting: evidence from aligned scoria cones and maars Journal of Volcanology and Geothermal Research, 201(1-4): 83-96.

Rooney, T.O., Hanan, B.B., Graham, D.W., Furman, T., Blichert-Toft, J. and Schilling, J.-G., 2012a. Upper Mantle Pollution during Afar Plume-Continental Rift Interaction. Journal of Petrology, 53: 365-389.

Rooney, T.O., Hart, W.K., Hall, C.M., Ayalew, D., Ghiorso, M.S., Hidalgo, P. and Yirgu, G., 2012b. Peralkaline magma evolution and the tephra record in the Ethiopian Rift Contributions to Mineralogy and Petrology, DOI: 10.1007/s00410-012-07446.

Rooney, T.O., Herzberg, C. and Bastow, I.D., 2012c. Elevated mantle temperature beneath East Africa. Geology, 40(1): 27-30.

Samson, S.D. and Alexander, E.C., 1987. Calibration of the interlaboratory Ar-40 Ar-39 dating standard, Mmhb-1. Chemical Geology, 66(1-2): 27-34.

Schilling, J.G., 1973. Afar Mantle Plume - rare-earth evidence. Nature-Physical Science, 242(114): 2-5.

Schilling, J.G., Kingsley, R.H., Hanan, B.B. and McCully, B.L., 1992. Nd-Sr-Pb isotopic variations along the Gulf of Aden - Evidence for Afar mantle plume continental lithosphere interaction. Journal of Geophysical Research-Solid Earth, 97(B7): 10927-10966.

Schultz, R.A., Soliva, R., Fossen, H., Okubo, C.H. and Reeves, D.M., 2008. Dependence of displacement-length scaling relations for fractures and deformation bands on the volumetric changes across them. Journal of Structural Geology, 30(11): 1405-1411.

Sleep, N.H., 2008. Channeling at the base of the lithosphere during the lateral flow of plume material beneath flow line hot spots. Geochemistry Geophysics Geosystems, 9: Q08005, doi:10.1029/2008GC002090.

Sobolev, A.V., Hofmann, A.W., Kuzmin, D.V., Yaxley, G.M., Arndt, N.T., Chung, S.L., Danyushevsky, L.V., Elliott, T., Frey, F.A., Garcia, M.O., Gurenko, A.A., Kamenetsky, V.S., Kerr, A.C., Krivolutskaya, N.A., Matvienkov, V.V., Nikogosian, I.K., Rocholl, A., Sigurdsson, I.A., Sushchevskaya, N.M. and Teklay, M., 2007. The amount of recycled crust in sources of mantle-derived melts. Science, 316(5823): 412-417.

Sobolev, A.V., Hofmann, A.W., Sobolev, S.V. and Nikogosian, I.K., 2005. An olivine-free mantle source of Hawaiian shield basalts. Nature, 434(7033): 590-597.

Stewart, K. and Rogers, N., 1996. Mantle plume and lithosphere contributions to basalts from southern Ethiopia. Earth and Planetary Science Letters, 139(1-2): 195-211.

Sun, S.s.-. and McDonough, W.F., 1989. Chemical and isotopic systematics of oceanic basalts: Implications for mantle composition and processes. In: Saunders, A.D. (Eds), Magmatism in the ocean basins. Geological Society, London, 313 - 345.

Tanaka, T., Togashi, S., Kamioka, H., Amakawa, H., Kagami, H., Hamamoto, T., Yuhara, M., Orihashi, Y., Yoneda, S., Shimizu, H., Kunimaru, T., Takahashi, K., Yanagi, T., Nakano, T., Fujimaki, H., Shinjo, R., Asahara, Y., Tanimizu, M. and Dragusanu, C., 2000. JNdi-1: a neodymium isotopic reference in consistency with LaJolla neodymium. Chemical Geology, 168(3-4): 279-281. 
1301

1302

1303

1304

1305

1306

1307

1308

1309

1310

1311

1312

1313

1314

1315

1316

1317

1318

1319

1320

1321

1322

1323

1324

1325

1326

1327

1328

1329

1330

1331

1332

1333

1334

1335

1336

1337

1338

1339

1340

1341

1342

1343

1344

1345

Tegner, C., Lesher, C.E., Larsen, L.M. and Watt, W.S., 1998. Evidence from the rareearth-element record of mantle melting for cooling of the tertiary Iceland plume. Nature, 395(6702): 591-594.

Tilton, G.R., 1973. Isotopic lead ages of chondritic meteorites. Earth and Planetary Science Letters, 19(3): 321-329.

Trua, T., Deniel, C. and Mazzuoli, R., 1999. Crustal control in the genesis of PlioQuaternary bimodal magmatism of the Main Ethiopian Rift (MER); geochemical and isotopic ( $\mathrm{Sr}, \mathrm{Nd}, \mathrm{Pb}$ ) evidence. Chemical Geology, 155(3-4): 201-231.

Turner, G. and Cadogan, P.H., 1974. Possible effects of 39Ar recoil in 40Ar dating. , Proceedings of the Fifth Lunar Science Conference, 1601-1615.

Turner, G., Enright, M.C. and Cadogan, P.H., 1978. The early history of chondrite parent bodies inferred from 40Ar-39Ar ages, Proceedings of the Lunar and Planetary Science Conference, 989-1025.

Ukstins, I.A., Renne, P.R., Wolfenden, E., Baker, J., Ayalew, D. and Menzies, M., 2002. Matching conjugate volcanic rifted margins; 40Ar/39Ar chrono-stratigraphy of pre- and syn-rift bimodal flood volcanism in Ethiopia and Yemen. Earth and Planetary Science Letters, 198(3-4): 289-306.

van Wijk, J., van Hunen, J. and Goes, S., 2008. Small-scale convection during continental rifting: Evidence from the Rio Grande rift. Geology, 36(7): 575-578.

Vogel, T.A., Flood, T.P., Patino, L.C., Wilmot, M.S., Maximo, R.P.R., Arpa, C.B., Arcilla, C.A. and Stimac, J.A., 2006. Geochemistry of silicic magmas in the Macolod Corridor, SW Luzon, Philippines: evidence of distinct, mantle-derived, crustal sources for silicic magmas. Contributions to Mineralogy and Petrology, 151(3): 267-281.

Walker, G.P.L., 1960. Zeolite zones and dike distribution in relation to the structure of the basalts of Eastern Iceland. Journal of Geology, 68(5): 515-528.

Walter, R.C., 1980. The volcanic history of the Hadar early-man site and the surrounding Afar region of Ethiopia, Ph.D., Case Western Reserve University, $426 \mathrm{pp}$.

Wang, K., Plank, T., Walker, J.D. and Smith, E.I., 2002. A mantle melting profile across the basin and range, SW USA. Journal of Geophysical Research-Solid Earth, 107(B1): 2017, doi:10.1029/2001JB0002092.

White, R. and McKenzie, D., 1989. Magmatism at rift zones - the generation of volcanic continental margins and flood basalts. Journal of Geophysical Research-Solid Earth and Planets, 94(B6): 7685-7729.

Wolfenden, E., Ebinger, C., Yirgu, G., Renne, P.R. and Kelley, S.P., 2005. Evolution of a volcanic rifted margin: Southern Red Sea, Ethiopia. Geological Society of America Bulletin, 117(7-8): 846-864.

Wright, T.J., Sigmundsson, C.P., C., Belachew, M., Hamling, I., Brandsdottir, B., Keir, D., Pedersen, R., Ayele, A., Ebinger, C., Einarsson, P., Lewi, E. and Calais, E., 2012. Geophysical constraints on the dynamics of spreading centres from 1 rifting episodes on land. Nature Geoscience, In Press.

Zanettin, B., 1992. Evolution of the Ethiopian Volcanic Province. Memorie Lincee Scienze Fisiche e Naturali, 1: 155-181. 


\begin{tabular}{|c|c|c|c|c|}
\hline Unit & Composition & Basin & Age & Dike Group \\
\hline $\begin{array}{l}\text { Dahla Series } \\
\text { unconformity }\end{array}$ & Fissure Basalts & 3 & c. $7-5 \mathrm{Ma}^{*}$ & 3 \\
\hline $\begin{array}{l}\text { Burka Formation } \\
\text { unconformity }\end{array}$ & Basalts, rhyolites & 2 & c. $20-13 \mathrm{Ma}$ & $4 a$ \\
\hline $\begin{array}{l}\text { Dese Formation } \\
\text { unconformity }\end{array}$ & Basalts & 1 & c. $29.5-24 \mathrm{Ma}$ & $1,4 b$ \\
\hline Ashangi, Aiba, Alaji & Flood basalts, rhyolites & throughout & c. $31.5-29.5^{* *}$ & 2 \\
\hline
\end{tabular}

* Renne et al., (1999)

** Hofmann et al., (1997)

Table 1. 


\begin{tabular}{|c|c|c|c|c|}
\hline \multirow[t]{2}{*}{ Sector } & \multicolumn{2}{|c|}{ 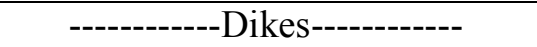 } & \multicolumn{2}{|c|}{------------Faults------------ } \\
\hline & Strike & Dip & Strike & Dip \\
\hline \multicolumn{5}{|c|}{ Desse-Combolcia: } \\
\hline & N000-010 & W & $\mathrm{N} 350-000^{\circ}$ & $\mathrm{W}, \mathrm{E}$ \\
\hline & N060 & near-vertical & N065-080 $0^{\circ}$ & NW \\
\hline \multicolumn{5}{|c|}{ Combolcia-Batie: } \\
\hline & $\mathrm{N} 330-350^{\circ}$ & W & $\mathrm{N} 335-350^{\circ}$ & $\mathrm{W}, \mathrm{E}$ \\
\hline & $\mathrm{N} 020-030^{\circ}$ & W & N020-040 & NW \\
\hline & $\mathrm{N} 045-060^{\circ}$ & NW,SE & N040-075 & NW \\
\hline & $\mathrm{N} 300^{\circ}$ & SW & & \\
\hline \multicolumn{5}{|l|}{ Batie-Eloa: } \\
\hline & $\mathrm{N} 330-350^{\circ}$ & $\mathrm{W}$ & $\mathrm{N} 340-350^{\circ}$ & $* *$ \\
\hline & N000-010 & $\mathrm{W}$ & N005-030 & W \\
\hline & N050-060 & near-vertical & N060-080 & NW \\
\hline
\end{tabular}

* This fault trend coincides with the axes of numerous small, gentle folds in the stratoid lavas.

** The NNW-trending faults of the Batie-Eloa sector dip predominantly W (with E upthrows), but in the easternmost, Eloa zone the slip planes dip E.

Table 2 


\begin{tabular}{|c|c|c|c|c|c|c|c|c|c|c|c|c|c|}
\hline Sample & Run & $\begin{array}{l}\text { TGA } \\
\text { (Ma) }\end{array}$ & $+/-$ & $\begin{array}{l}\text { RIA } \\
\text { (Ma) }\end{array}$ & $+/-$ & $\begin{array}{l}\text { EWP } \\
(\mathrm{Ma})\end{array}$ & $+/-$ & $\begin{array}{l}\text { CIA } \\
\text { (Ma) }\end{array}$ & $+/-$ & $\begin{array}{c}\text { Preferred } \\
\text { (Ma) }\end{array}$ & $+/-$ & $\begin{array}{c}\text { Megrue } \\
\mathrm{K}-\mathrm{Ar} \\
(\mathrm{Ma})\end{array}$ & $+/-$ \\
\hline \multirow[t]{3}{*}{ EAD-111 } & $\mathrm{a}$ & 24.67 & 0.25 & 24.67 & 0.25 & 24.27 & 0.17 & & & & & & \\
\hline & $b$ & 23.89 & 0.21 & 23.95 & 0.18 & 23.56 & 0.16 & & & & & & \\
\hline & Avg. & 24.20 & 0.39 & 24.21 & 0.34 & 23.90 & 0.36 & 23.57 & 0.17 & 23.57 & 0.17 & 23.9 & 2.0 \\
\hline \multirow[t]{3}{*}{ EAD-114 } & $\mathrm{a}$ & 24.43 & 0.06 & 24.76 & 0.06 & NA & - & & & & & & \\
\hline & b & 24.58 & 0.08 & 24.77 & 0.08 & NA & - & & & & & & \\
\hline & Avg. & 24.48 & 0.07 & 24.76 & 0.05 & - & - & 24.82 & 0.13 & 24.76 & 0.05 & 23.1 & 0.9 \\
\hline \multirow[t]{3}{*}{ EKA-112B } & $\mathrm{a}$ & 31.02 & 0.26 & 30.74 & 0.21 & 30.80 & 0.18 & & & & & & \\
\hline & b & 31.02 & 0.33 & 31.14 & 0.29 & 30.72 & 0.21 & & & & & & \\
\hline & Avg. & 31.02 & 0.20 & 30.88 & 0.19 & 30.77 & 0.14 & 30.75 & 0.16 & 30.77 & 0.14 & NA & NA \\
\hline \multirow[t]{4}{*}{ EKA-116 } & $\mathrm{a}$ & 28.56 & 0.34 & 29.85 & 0.21 & 29.79 & 0.19 & & & & & & \\
\hline & b & 28.94 & 0.41 & 29.36 & 0.37 & 29.14 & 0.28 & & & & & & \\
\hline & $\mathrm{c}$ & 28.65 & 0.30 & 28.87 & 0.24 & 29.79 & 0.22 & & & & & & \\
\hline & Avg. & 28.58 & 0.20 & 29.78 & 0.15 & 29.66 & 0.19 & 30.01 & 0.16 & 29.78 & 0.15 & 35.2 & 1.4 \\
\hline \multirow[t]{4}{*}{ EKA-119 } & $\mathrm{a}$ & 13.95 & 0.49 & 11.97 & 0.48 & 12.10 & 0.51 & & & & & & \\
\hline & b & 15.12 & 0.44 & 14.34 & 0.31 & 14.71 & 0.53 & & & & & & \\
\hline & $\mathrm{c}$ & 12.72 & 0.28 & 12.72 & 0.28 & 12.79 & 0.23 & & & & & & \\
\hline & Avg. & 13.51 & 0.71 & 13.20 & 0.65 & 12.95 & 0.53 & 12.51 & 0.33 & 12.51 & 0.33 & 15.7 & 1.1 \\
\hline \multirow[t]{4}{*}{ EKA-120 } & $\mathrm{a}$ & 27.69 & 0.34 & 27.96 & 0.32 & NA & & & & & & & \\
\hline & b & 28.05 & 0.46 & 28.29 & 0.43 & 25.96 & 0.51 & & & & & & \\
\hline & $\mathrm{c}$ & 26.71 & 0.21 & 26.90 & 0.21 & 26.15 & 0.29 & & & & & & \\
\hline & Avg. & 27.13 & 0.39 & 27.37 & 0.41 & 26.10 & 0.26 & 28.02 & 0.27 & 27.37 & 0.41 & 31.8 & 1.4 \\
\hline \multirow[t]{3}{*}{ EKA-140A } & $\mathrm{a}$ & 8.00 & 0.10 & 8.03 & 0.09 & NA & - & & & & & & \\
\hline & b & 8.61 & 0.11 & 8.72 & 0.11 & 9.21 & 0.12 & & & & & & \\
\hline & Avg. & 8.26 & 0.30 & 8.31 & 0.34 & - & - & 8.18 & 0.30 & 8.31 & 0.34 & 19.6 & 1.1 \\
\hline \multirow[t]{3}{*}{ EKA-153 } & $\mathrm{a}$ & 18.67 & 0.07 & 20.47 & 0.09 & NA & - & & & & & & \\
\hline & $b$ & 19.83 & 0.07 & 20.59 & 0.06 & NA & - & & & & & & \\
\hline & Avg. & 19.34 & 0.57 & 20.55 & 0.06 & - & - & 21.23 & 0.36 & 20.55 & 0.06 & NA & NA \\
\hline
\end{tabular}

Table 3. 


\begin{tabular}{lcccccccccccc}
\hline Sample & ${ }^{87} \mathrm{Sr} /{ }^{86} \mathrm{Sr}$ & $2 \sigma$ & ${ }^{143} \mathrm{Nd} /{ }^{144} \mathrm{Nd}$ & $2 \sigma$ & ${ }^{206} \mathrm{~Pb} /{ }^{204} \mathrm{~Pb}$ & $2 \sigma$ & ${ }^{207} \mathrm{~Pb} /{ }^{204} \mathrm{~Pb}$ & $2 \sigma$ & ${ }^{208} \mathrm{~Pb} /{ }^{204} \mathrm{~Pb}$ & $2 \sigma$ & ${ }^{176} \mathrm{Hf} /{ }^{177} \mathrm{Hf}$ & $2 \sigma$ \\
\hline EKA-116 & 0.704713 & 9 & 0.512710 & 7 & 18.9293 & 9 & 15.6445 & 9 & 39.0598 & 26 & 0.282983 & 10 \\
EKA-120 & 0.704722 & 8 & 0.512686 & 4 & 19.1851 & 13 & 15.6450 & 12 & 39.3051 & 35 & 0.282898 & 14 \\
EKA-112B & 0.704745 & 8 & 0.512781 & 6 & 18.2061 & 10 & 15.5638 & 9 & 38.4707 & 28 & 0.282995 & 13 \\
EKA-140A & 0.703647 & 6 & 0.512932 & 5 & 18.2683 & 12 & 15.5452 & 12 & 38.5000 & 34 & 0.283088 & 9 \\
EKA-142 & 0.703449 & 10 & 0.512950 & 5 & 18.2285 & 10 & 15.5337 & 10 & 38.4161 & 24 & 0.283089 & 10 \\
EKA-106 & 0.704443 & 8 & 0.512735 & 5 & 17.9460 & 8 & 15.5449 & 10 & 38.3195 & 30 & 0.282904 & 8 \\
EKA-153 & 0.705482 & 10 & 0.512709 & 6 & 18.0249 & 11 & 15.5863 & 11 & 38.5694 & 30 & 0.282893 & 9 \\
EKA-119 & 0.704333 & 8 & 0.512827 & 6 & 18.5287 & 10 & 15.5897 & 10 & 38.9792 & 33 & 0.282994 & 8 \\
EAD-111 & 0.704514 & 8 & 0.512845 & 4 & 18.8366 & 12 & 15.6562 & 12 & 39.2479 & 34 & 0.283011 & 11 \\
EAD-113 & 0.704286 & 9 & 0.512906 & 6 & 18.9878 & 9 & 15.6600 & 10 & 39.3444 & 30 & 0.283043 & 8 \\
EAD-116 & 0.704101 & 12 & 0.512915 & 4 & 19.3556 & 10 & 15.6960 & 10 & 39.6695 & 27 & 0.283060 & 10 \\
EAD-114 & 0.706728 & 8 & 0.512589 & 7 & 18.2142 & 8 & 15.6332 & 8 & 38.9070 & 22 & 0.282769 & 8 \\
\hline
\end{tabular}

Table 4. 


\begin{tabular}{lrrr}
\hline Element & PC1 & PC2 & PC3 \\
\hline $\mathrm{La}$ & 0.27 & -0.30 & 0.15 \\
$\mathrm{Ce}$ & 0.30 & -0.18 & 0.21 \\
$\mathrm{Pr}$ & 0.31 & -0.14 & 0.06 \\
$\mathrm{Nd}$ & 0.32 & 0.00 & 0.03 \\
$\mathrm{Sm}$ & 0.29 & 0.24 & 0.10 \\
$\mathrm{Eu}$ & 0.23 & 0.36 & -0.75 \\
$\mathrm{Gd}$ & 0.15 & 0.53 & -0.04 \\
$\mathrm{~Tb}$ & -0.08 & 0.56 & 0.55 \\
$\mathrm{Dy}$ & -0.29 & 0.23 & 0.06 \\
$\mathrm{Ho}$ & -0.32 & 0.05 & 0.02 \\
$\mathrm{Er}$ & -0.32 & -0.04 & 0.01 \\
$\mathrm{Yb}$ & -0.31 & -0.09 & -0.17 \\
$\mathrm{Lu}$ & -0.31 & -0.12 & -0.10 \\
\hline $\mathrm{Ta}$ & & &
\end{tabular}

Table 5 


\begin{tabular}{lcccccc}
\hline End member & $\varepsilon_{\mathrm{Nd}}$ & $\varepsilon_{\mathrm{Hf}}$ & ${ }^{87} \mathrm{Sr} /{ }^{86} \mathrm{Sr}$ & ${ }^{206} \mathrm{~Pb} /{ }^{204} \mathrm{~Pb}$ & ${ }^{207} \mathrm{~Pb} / 204 \mathrm{~Pb}$ & ${ }^{208} \mathrm{~Pb} /{ }^{204} \mathrm{~Pb}$ \\
\hline Pan African Lithosphere & -10.49 & -15.35 & 0.7075 & 17.85 & 15.75 & 39.75 \\
Depleted Mantle & 13.89 & 22.24 & 0.7022 & 17.5 & 15.3 & 36.6 \\
Afar Plume & 4.62 & 9.27 & 0.7035 & 19.5 & 15.6 & 39.2 \\
\hline
\end{tabular}

Table 6 
Figure 1

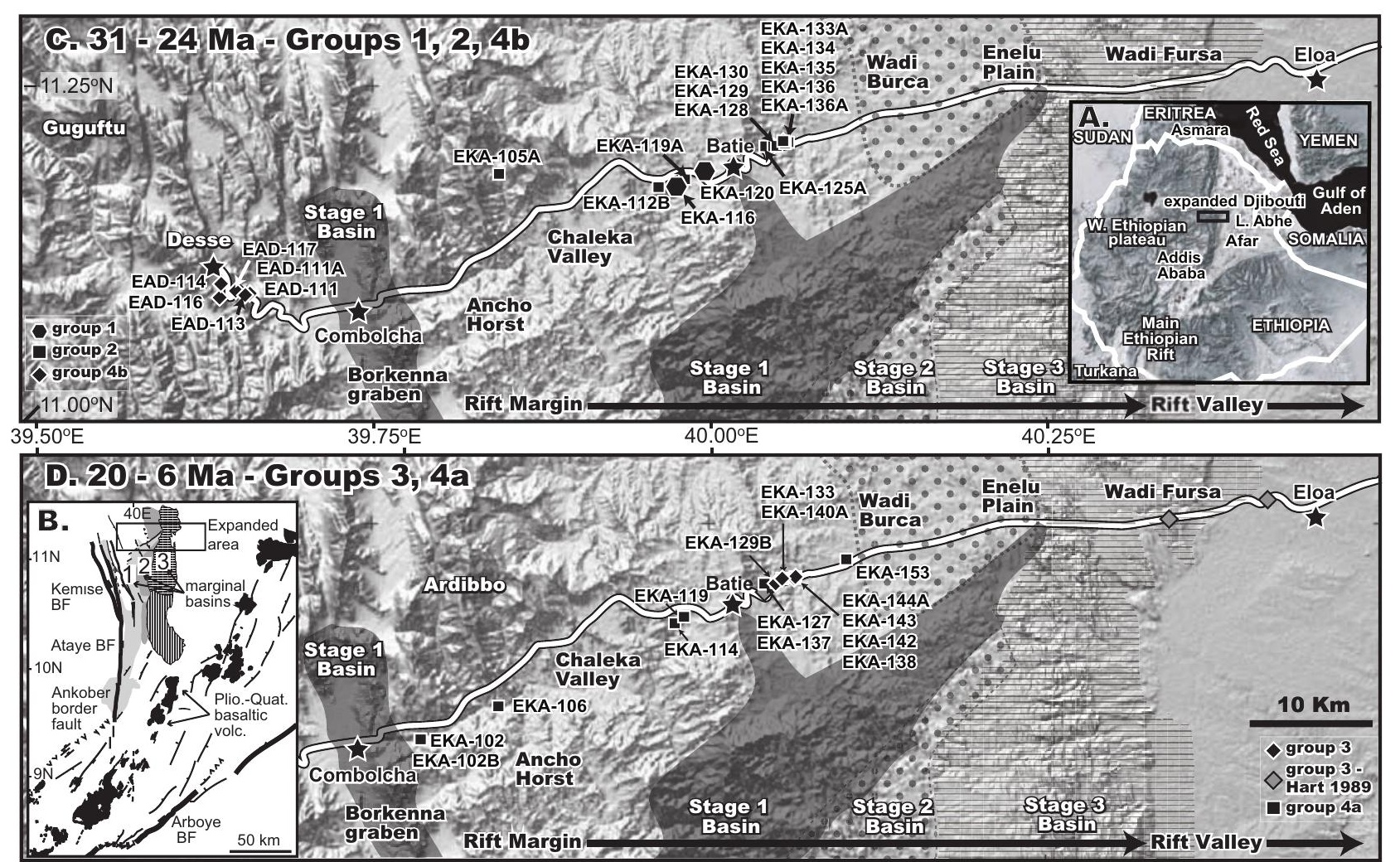



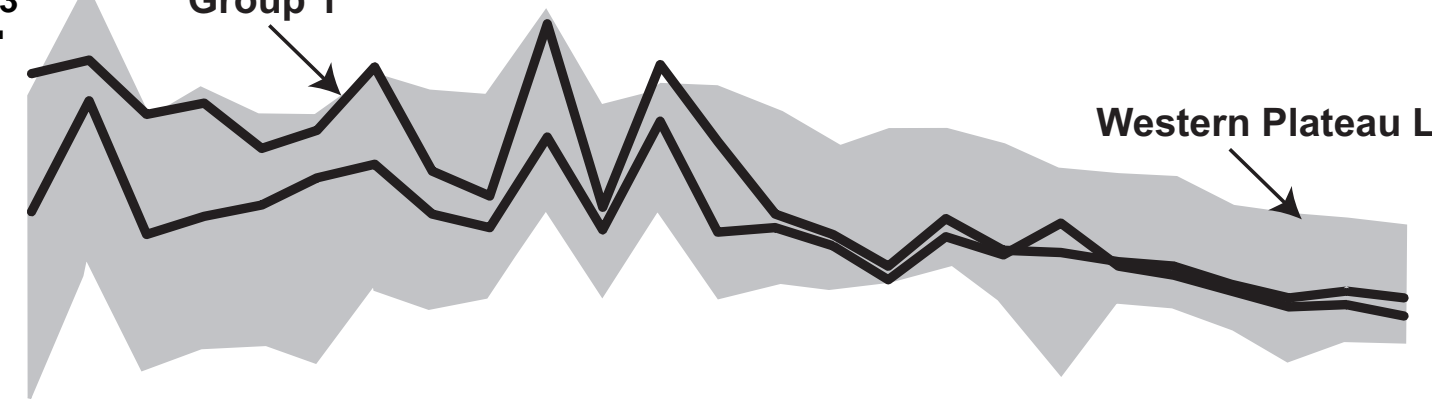

1

Rb Ba Th U Nb Ta K La Ce Pb Pr Sr P Nd Sm Zr Hf Eu Ti Gd Tb Dy Y Ho Er Tm Yb Lu

${ }^{100}$ [B.

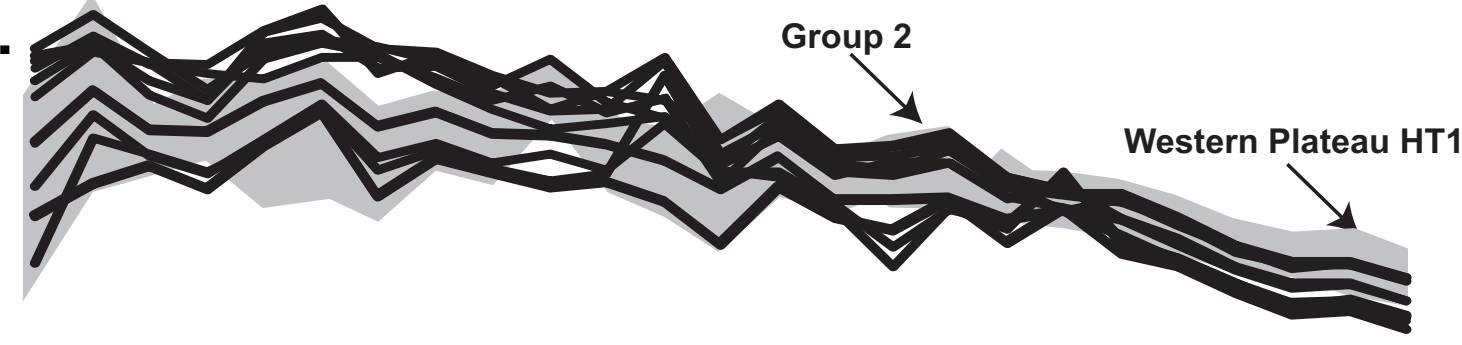

Rb Ba Th U Nb Ta K La CePb Pr Sr P Nd Sm Zr Hf Eu Ti Gd Tb Dy Y Ho Er Tm Yb Lu

C.
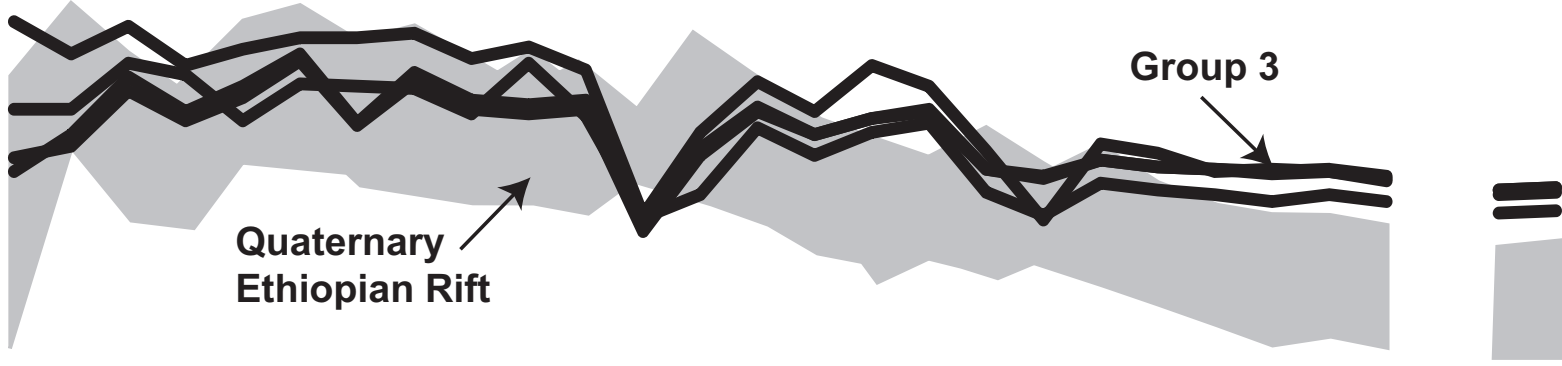

Rb Ba Th U Nb Ta K La CePb Pr Sr P Nd Sm Zr Hf Eu Ti Gd Tb Dy Y Ho Er Tm Yb Lu

D.

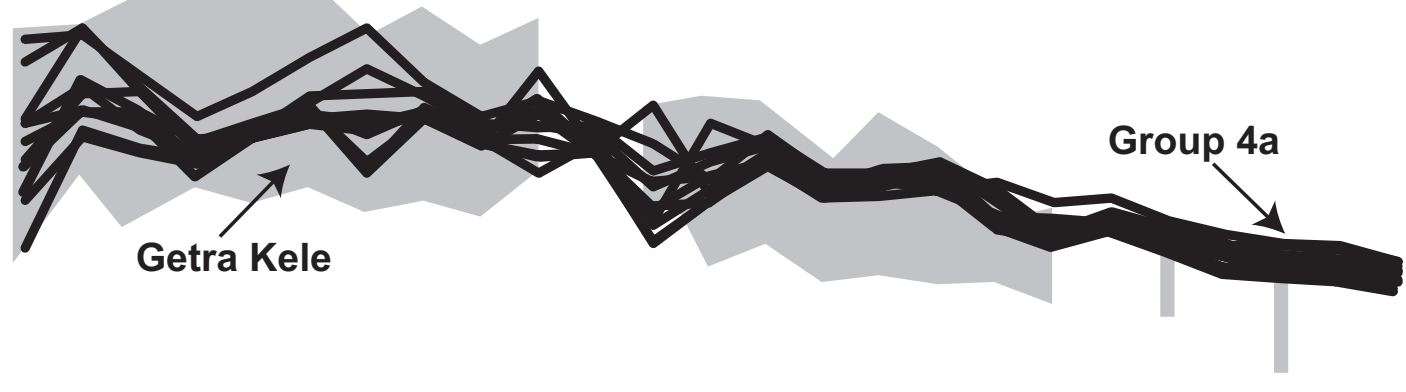

Rb Ba Th U Nb Ta K La CePb Pr Sr P Nd Sm Zr Hf Eu Ti Gd Tb Dy Y Ho Er Tm Yb Lu

\section{Guguftu}

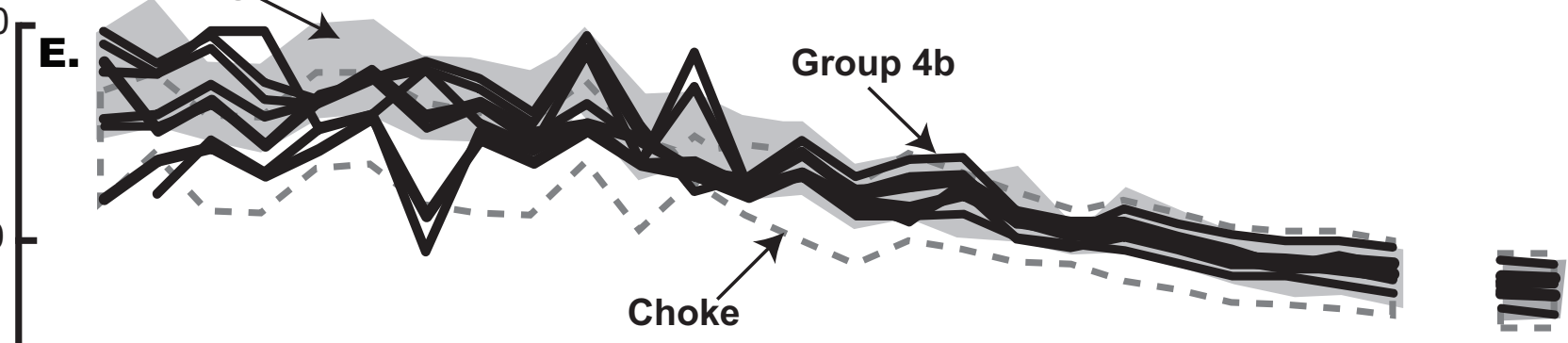



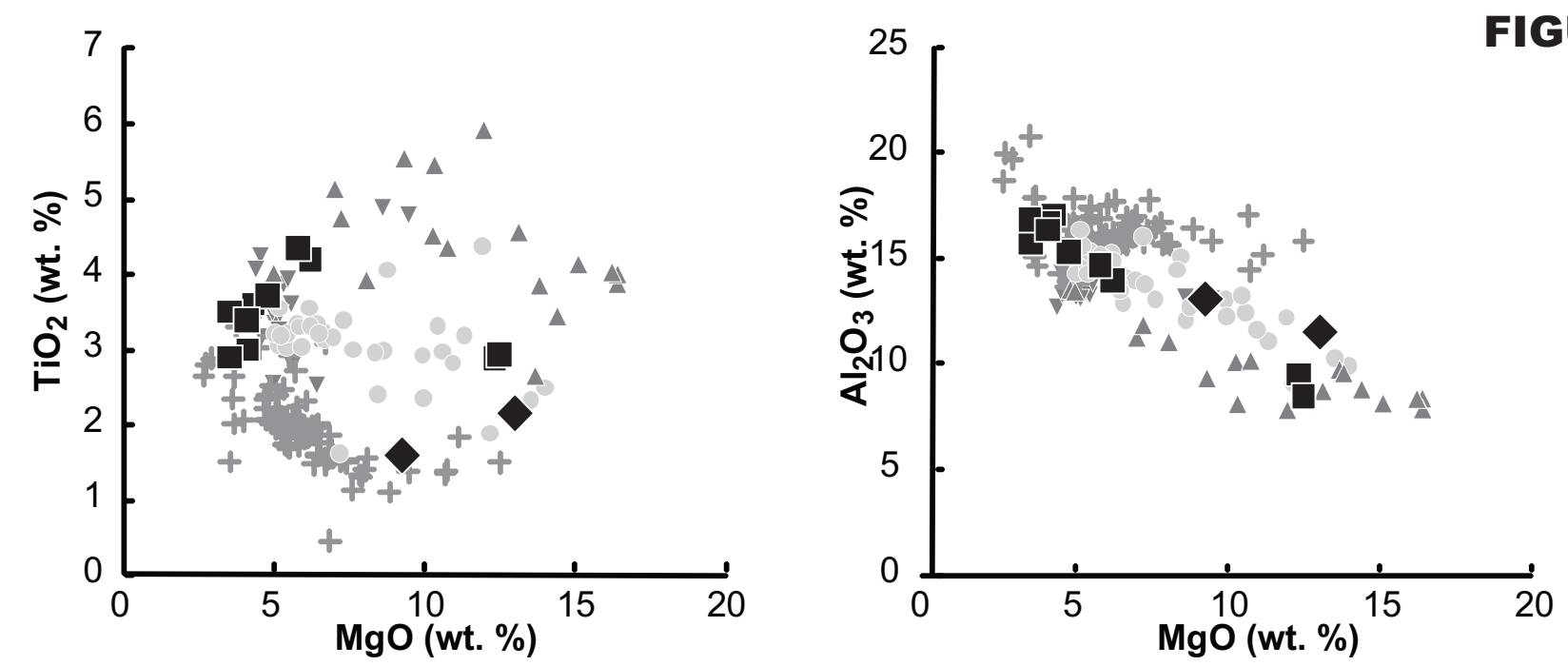

FIGURE 4A
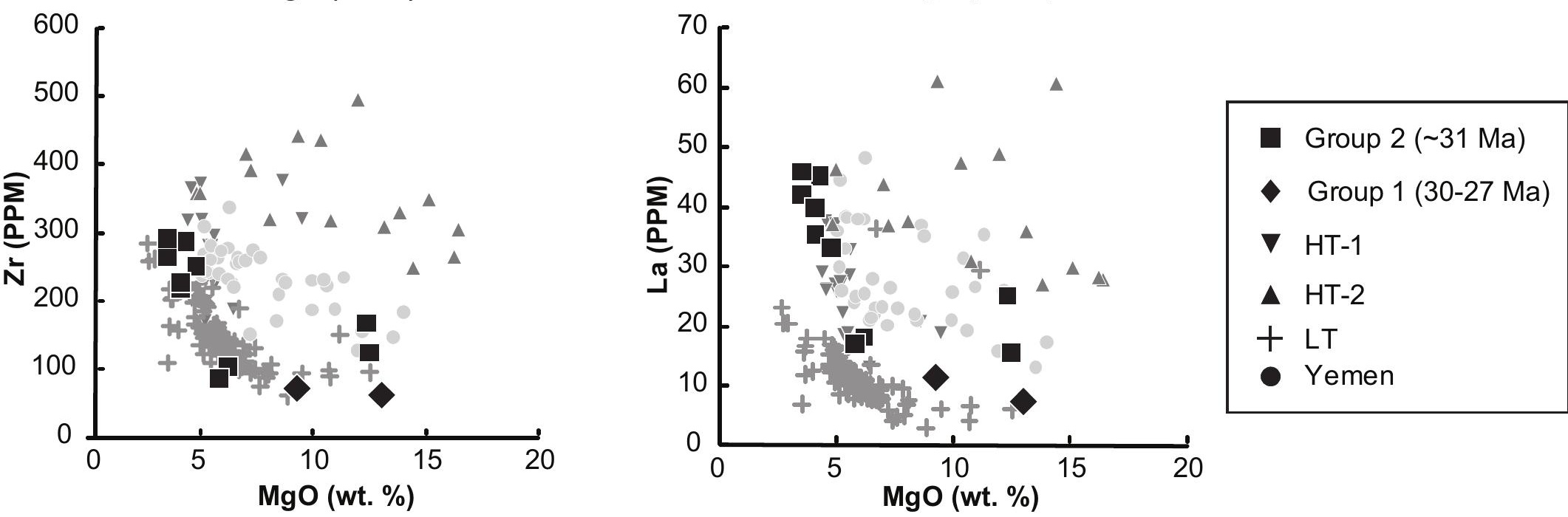

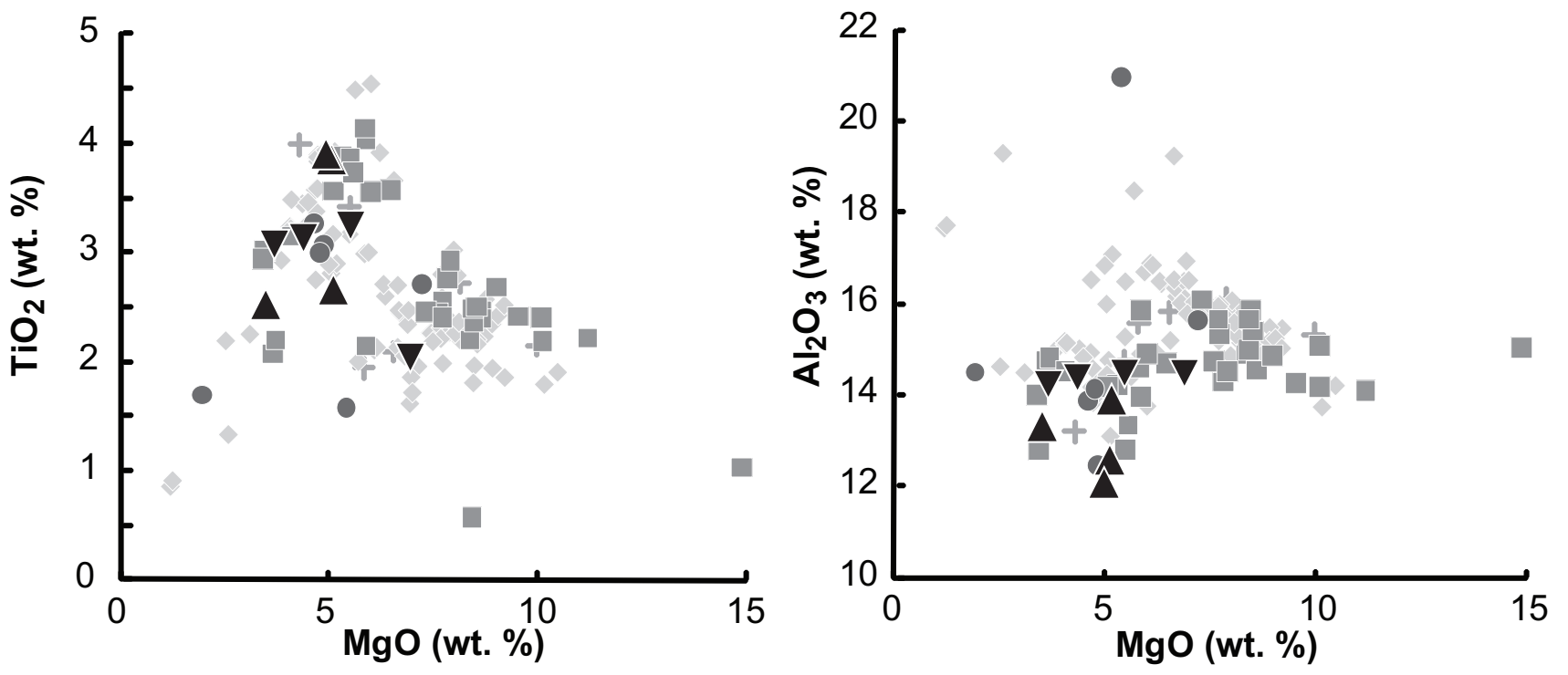

FIGURE 4B
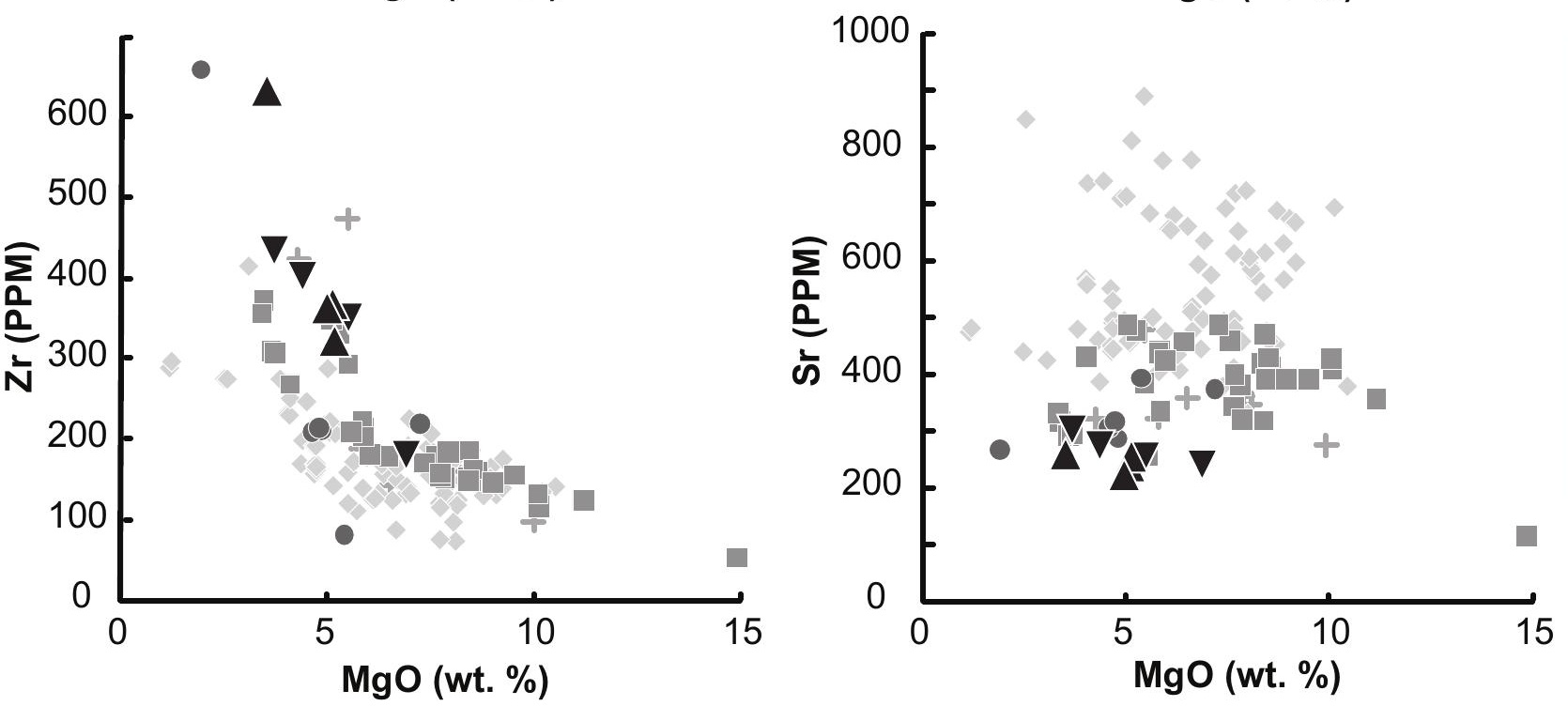
- Group 3 (<10 Ma)
- Hart et al.,
(1989)
MER
Djbouti
- Asal Rift
+ Dahla series



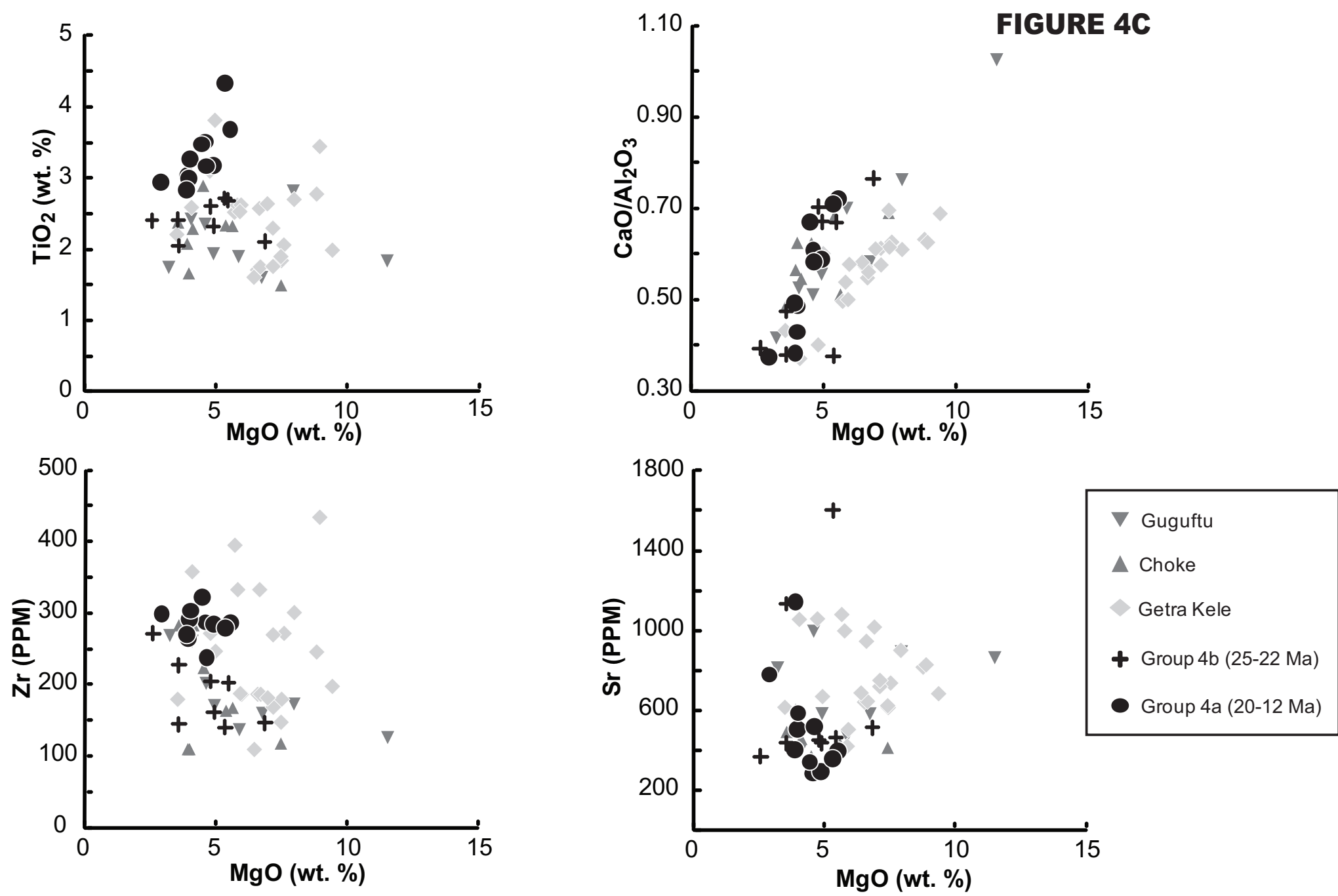
Figure 5a

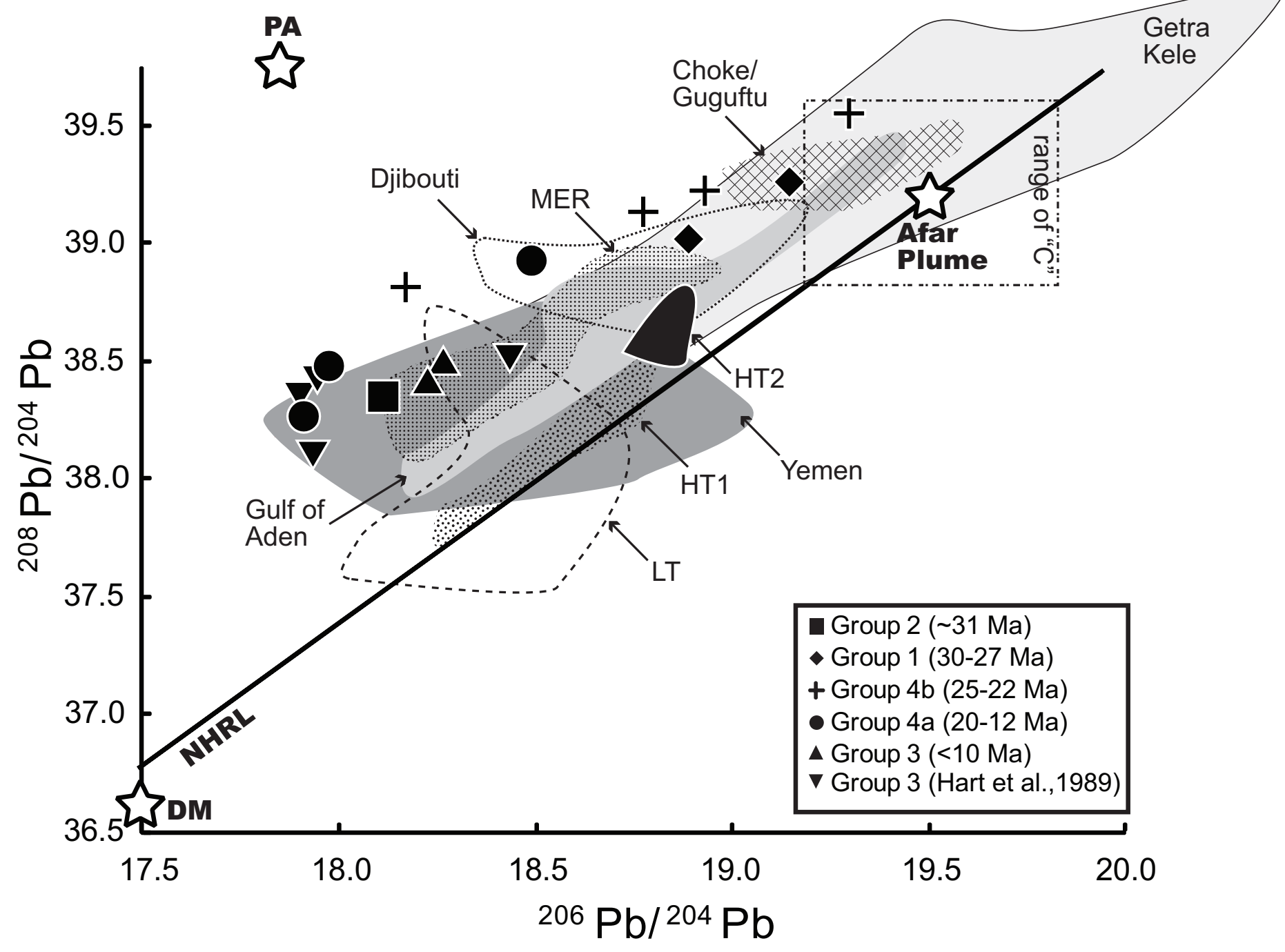




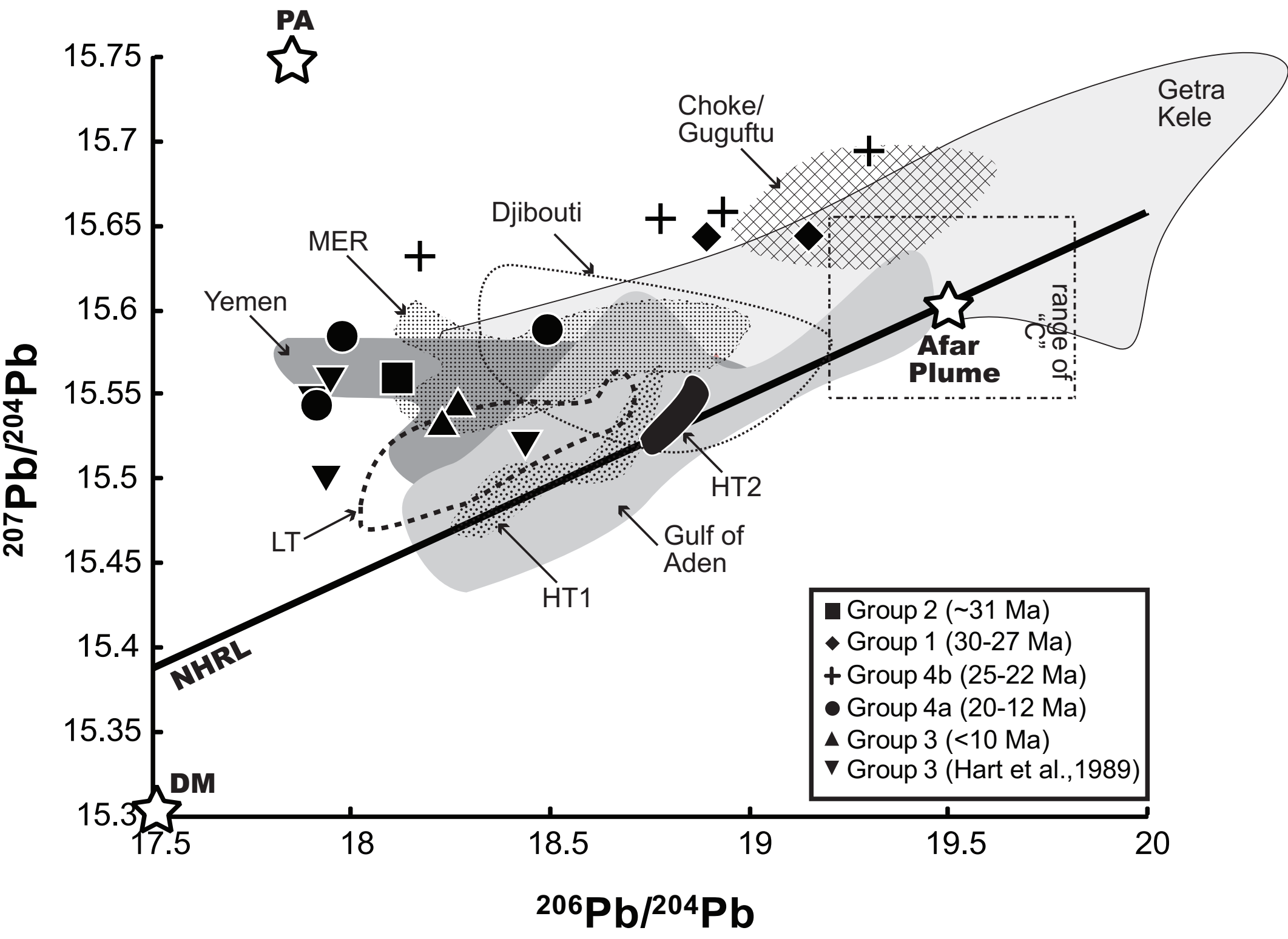


Figure 6

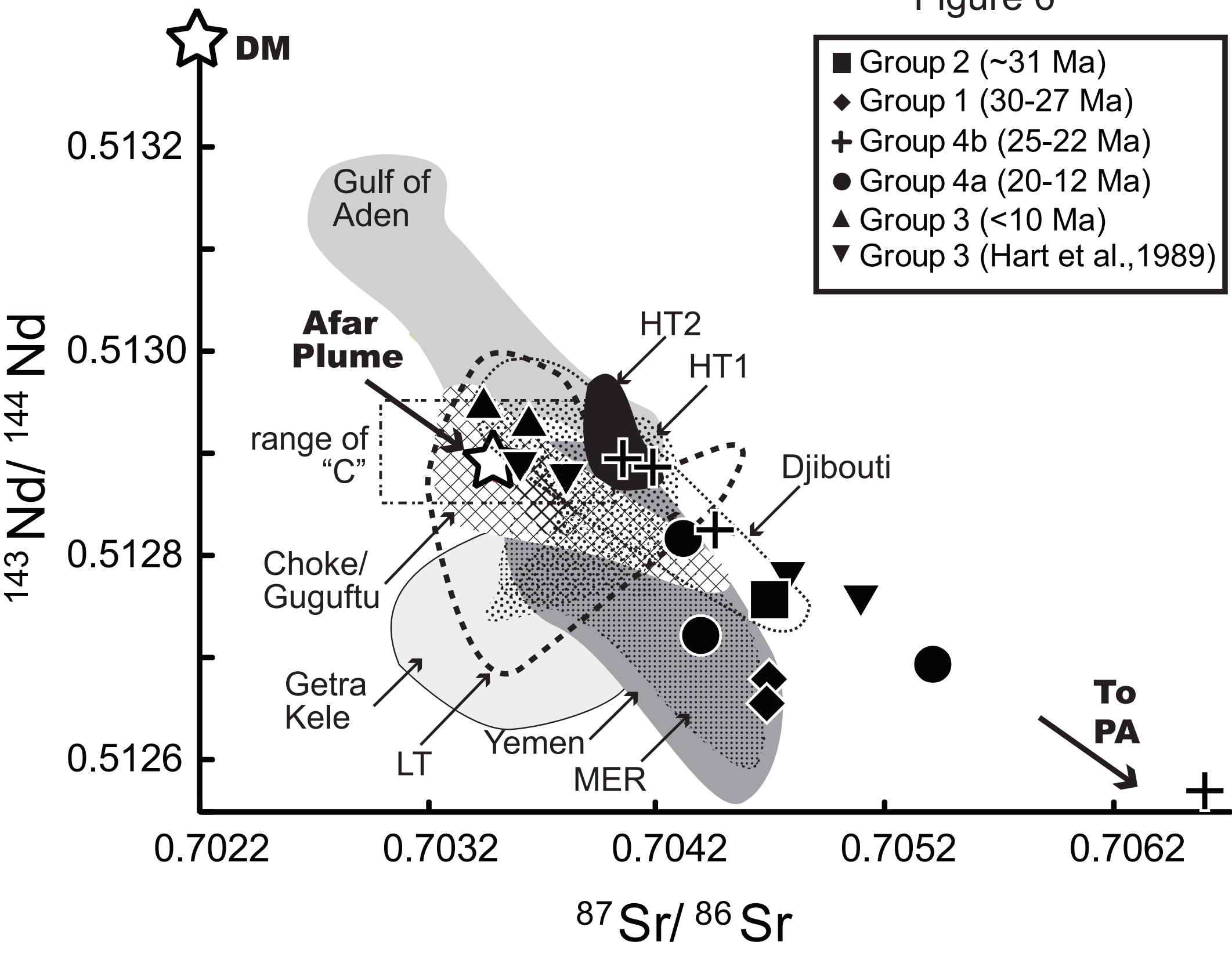


FIGURE 7

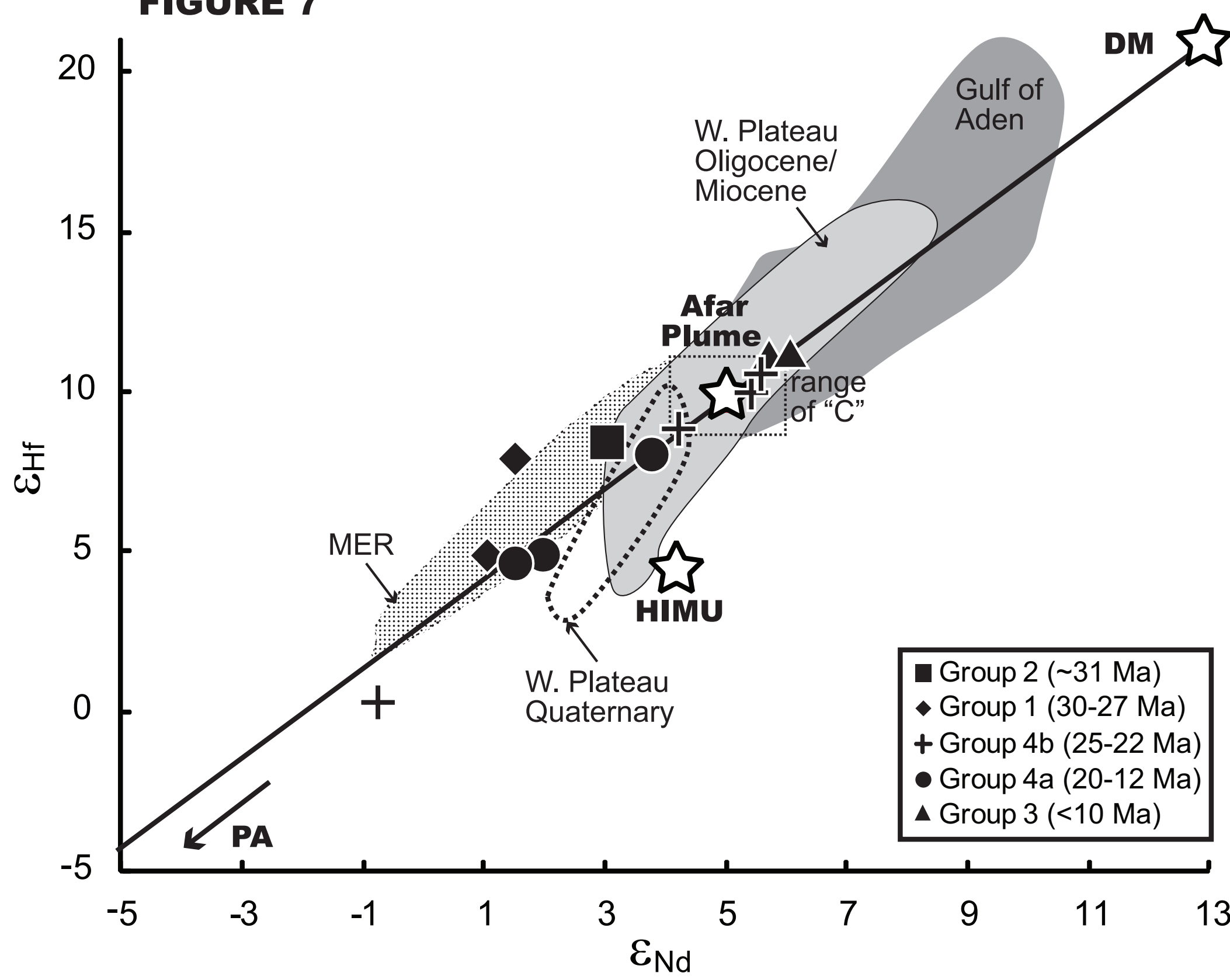




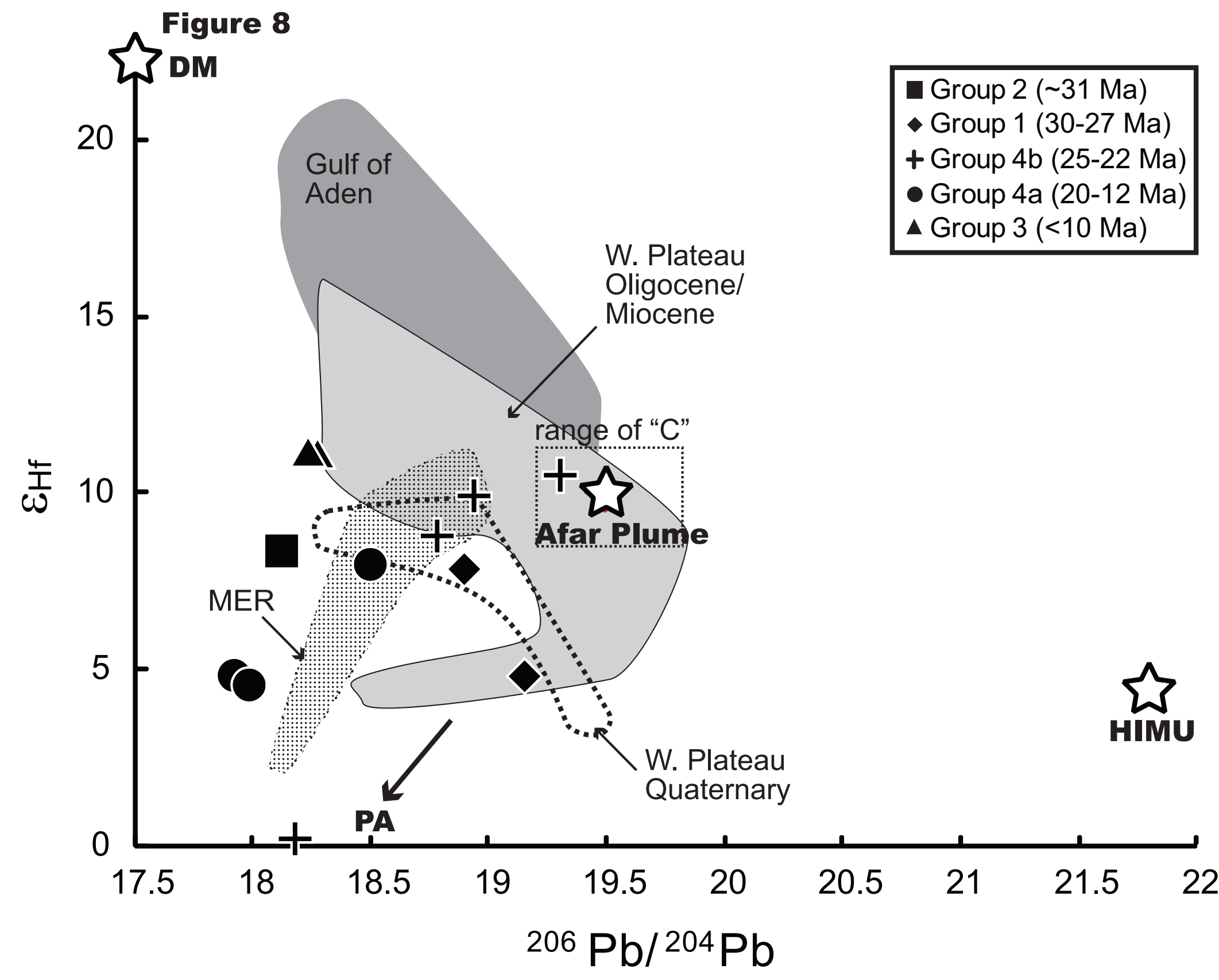


LREE low/ MREE high

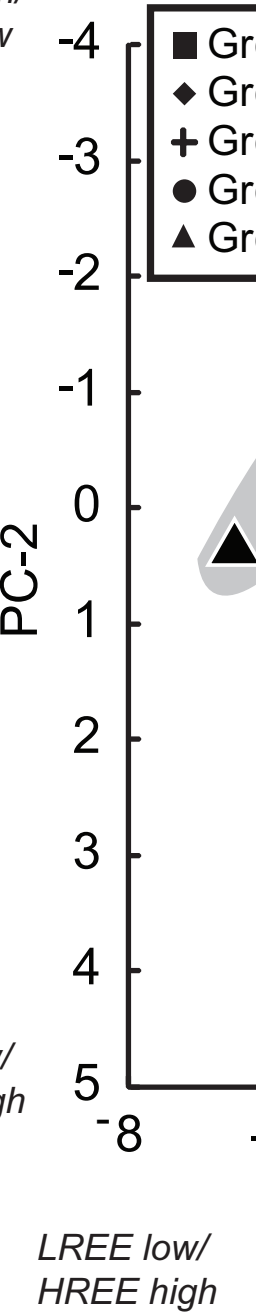

Group 2 ( 31 Ma)

- Group 1 (30-27 Ma)

a)

+
+4

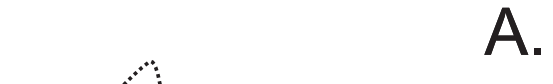

A.

Figure 9

HREE high

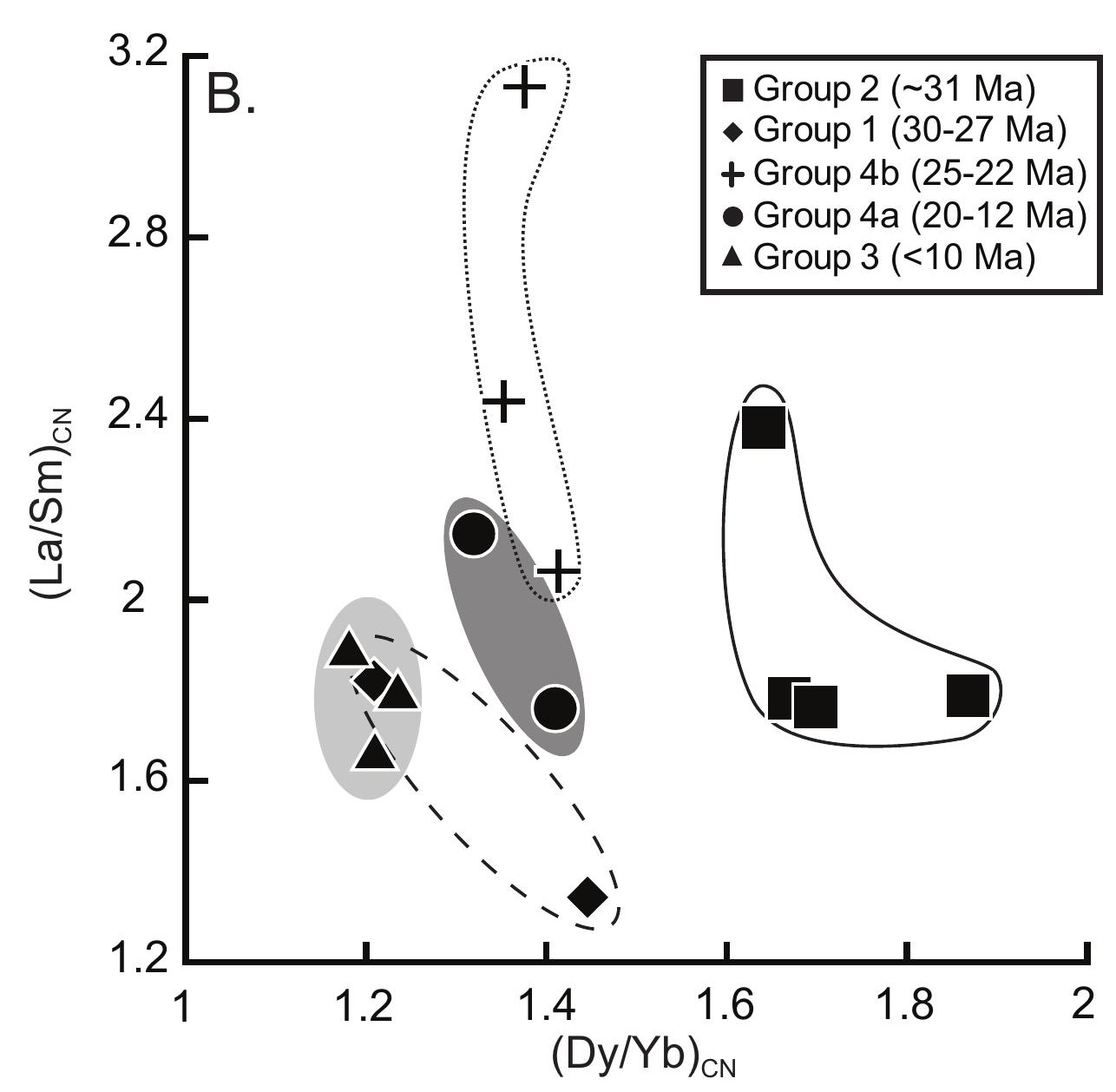

LREE high/

HREE IOW 
Figure 10

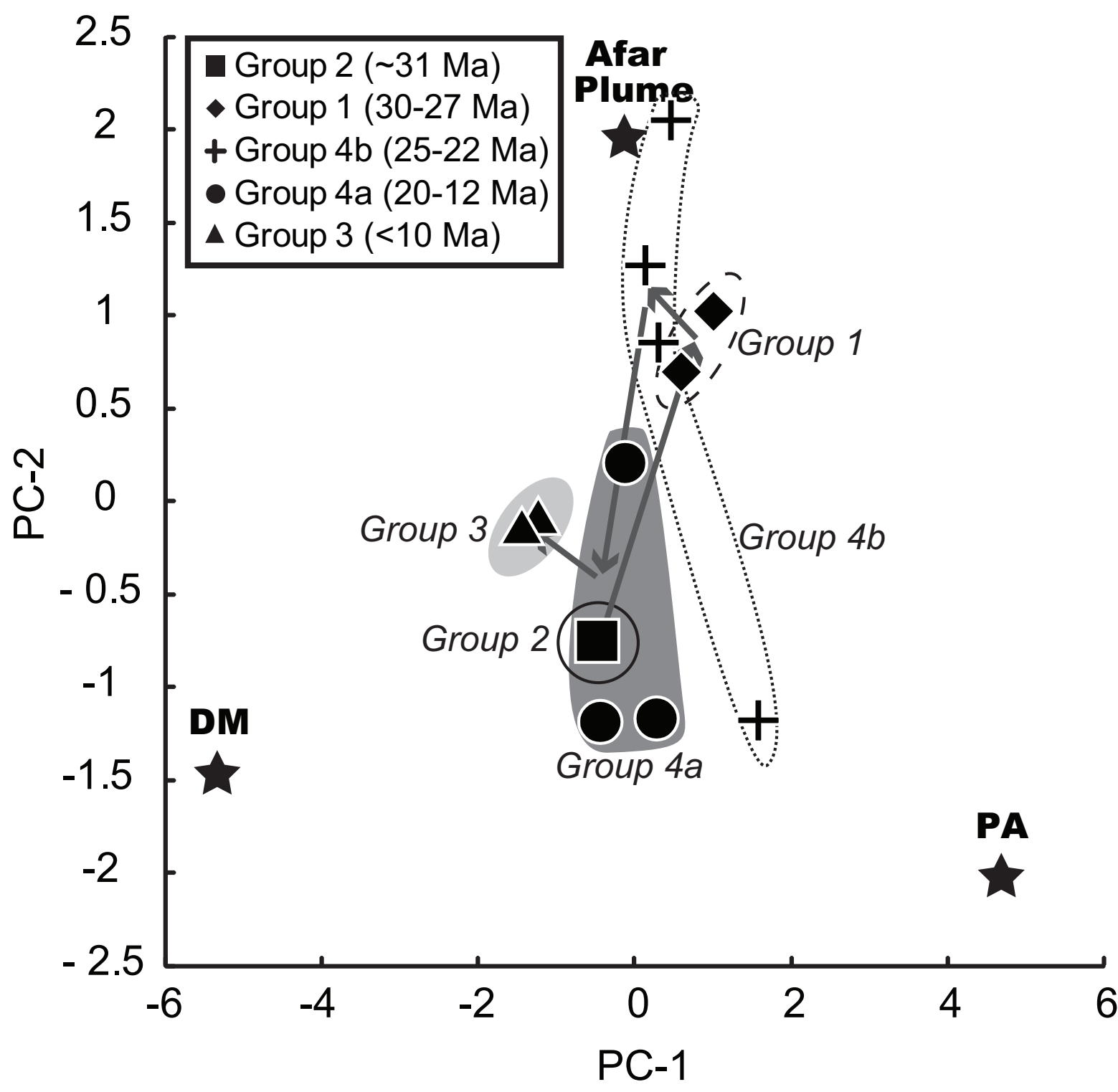




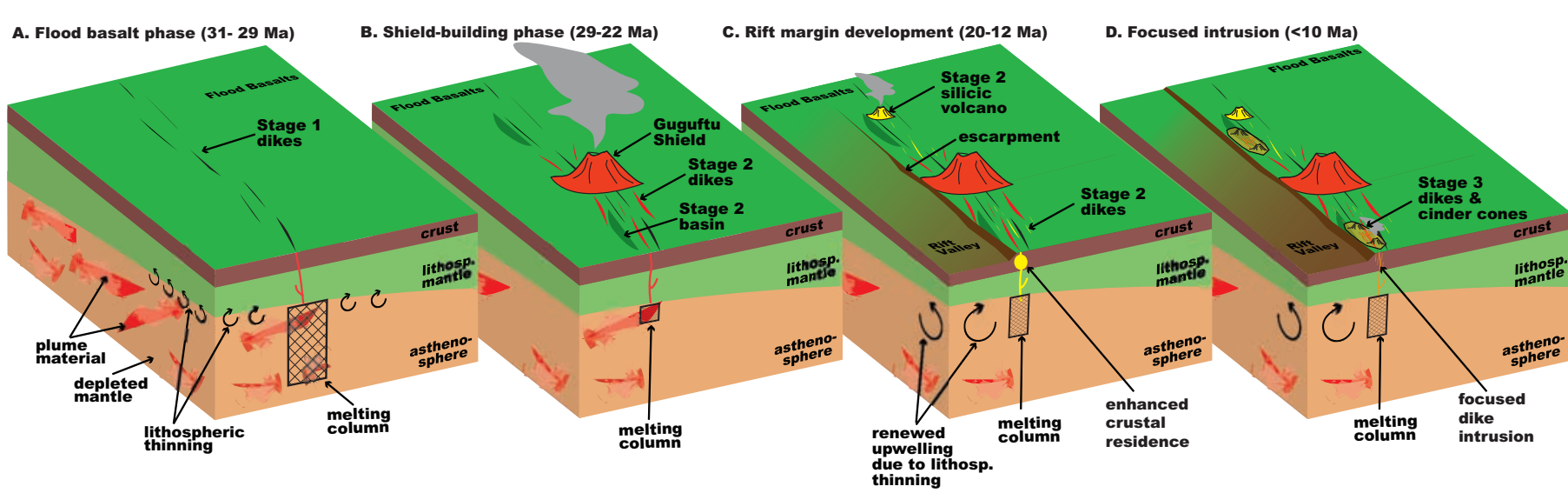

Figure 11 